\title{
What determines horizontal merger antitrust case selection?
}

DOI:

10.1016/j.jcorpfin.2017.06.007

\section{Document Version}

Accepted author manuscript

Link to publication record in Manchester Research Explorer

\section{Citation for published version (APA):}

Gao, N., Peng, N., \& Strong, N. (2017). What determines horizontal merger antitrust case selection? Journal of Corporate Finance, 46(0), 51-76. https://doi.org/10.1016/j.jcorpfin.2017.06.007

\section{Published in:}

Journal of Corporate Finance

\section{Citing this paper}

Please note that where the full-text provided on Manchester Research Explorer is the Author Accepted Manuscript or Proof version this may differ from the final Published version. If citing, it is advised that you check and use the publisher's definitive version.

\section{General rights}

Copyright and moral rights for the publications made accessible in the Research Explorer are retained by the authors and/or other copyright owners and it is a condition of accessing publications that users recognise and abide by the legal requirements associated with these rights.

\section{Takedown policy}

If you believe that this document breaches copyright please refer to the University of Manchester's Takedown Procedures [http://man.ac.uk/04Y6Bo] or contact uml.scholarlycommunications@manchester.ac.uk providing relevant details, so we can investigate your claim.

\section{OPEN ACCESS}




\section{Accepted Manuscript}

What determines horizontal merger antitrust case selection?

Ning Gao, Ni Peng, Norman Strong

PII: $\quad$ S0929-1199(17)30223-7

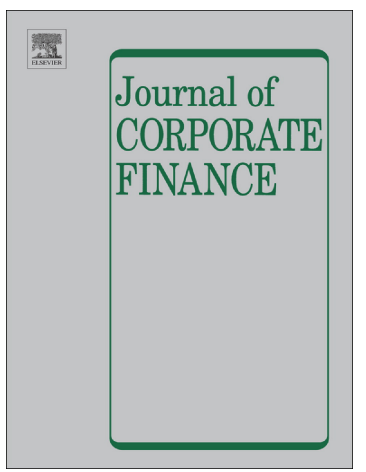

DOI: $\quad$ doi: $10.1016 /$ j.jcorpfin.2017.06.007

Reference: $\quad$ CORFIN 1220

To appear in: $\quad$ Journal of Corporate Finance

Received date: $\quad 11$ April 2017

Revised date: \#\#\#REISEDDATE\#\#\#

Accepted date: 19 June 2017

Please cite this article as: Ning Gao, Ni Peng, Norman Strong, What determines horizontal merger antitrust case selection?, Journal of Corporate Finance (2016), doi: 10.1016/ j.jcorpfin.2017.06.007

This is a PDF file of an unedited manuscript that has been accepted for publication. As a service to our customers we are providing this early version of the manuscript. The manuscript will undergo copyediting, typesetting, and review of the resulting proof before it is published in its final form. Please note that during the production process errors may be discovered which could affect the content, and all legal disclaimers that apply to the journal pertain. 


\title{
What determines horizontal merger antitrust case selection?
}

\author{
Ning Gao \\ Alliance Manchester Business School \\ University of Manchester \\ Manchester, UK \\ Email: ning.gao@mbs.ac.uk \\ Tel: (+44) 1612754847

\section{Ni Peng} \\ School of Business and Management \\ Queen Mary University of London \\ London, UK \\ Email: n.peng@qmul.ac.uk \\ Tel: (+44) 2078828413 \\ Norman Strong \\ Alliance Manchester Business School \\ University of Manchester \\ Manchester, UK \\ Email: norman.strong@mbs.ac.uk \\ Tel: (+44) 1612754006
}

\section{March 2017}

Keywords: horizontal merger; antitrust efficiency; case selection

JEL Classification: G34; K21 
What determines horizontal merger antitrust case selection?

\begin{abstract}
U.S. antitrust agencies claim their antitrust enforcement mission is to protect consumers, promote fair competition, and maintain efficiency. Are antitrust practices consistent with this claim? We explore this question by examining antitrust selection of horizontal merger cases in the U.S. manufacturing sector during 1980-2009. We find that antitrust agencies are more likely to intervene when foreign import pressure is low, merger industry concentration hits a hurdle level, or local or less specialized rivals suffer unfavorable wealth effects. We find no evidence that antitrust agencies systematically respond to the wealth effects of either customers in general or more affected customers. Our findings can be a useful reference for calibrating the efficiency of antitrust regulation and enforcement.
\end{abstract}

Keywords: horizontal merger; antitrust efficiency; case selection

Classification: G34; K21 


\section{Introduction}

Antitrust enforcement has played an important role in the United States for decades. The Department of Justice (DOJ) and the Federal Trade Commission (FTC) have authority to file antitrust complaints against a merger when they believe the merger would substantially weaken competition and violate antitrust laws. ${ }^{1}$ To avoid overlapping effort, they divide their jurisdiction and coordinate their activities. Both the DOJ and the FTC may file civil antitrust cases that violate the Clayton Act, but only the DOJ may bring criminal lawsuits under the Sherman Act. Before mounting a preliminary investigation against a merger, each requests clearance from the other (Bruner, 2004, p.745). In practice, most business combination complaints are against horizontal mergers (Eckbo, 1988). Despite a considerable literature exploring antitrust regulation efficiency and the intensity of aggregate antitrust activities (measured by the number of cases in a year) in the areas of financial economics, political economy, and law, ${ }^{2}$ the literature is silent on what determines antitrust case selection of horizontal mergers at the deal level. Nor is it conclusive to what extent the antitrust agencies fulfil their mission statement, i.e., to protect consumers, promote fair competition, and maintain efficiency.

We examine the determinants of antitrust challenges against horizontal mergers by empirically modelling the antitrust decision process. We draw on economic theories of regulation and the literature on horizontal merger motives to derive four hypotheses that explain the likelihood that a horizontal merger faces antitrust intervention. First, public interest regulation theory (Pigou, 1932) suggests that government intervention corrects market failure and maximizes social welfare. Governments actively intervene when business combinations weaken competition, inflate input prices, and harm downstream companies, including end consumers. The prediction of this theory is that challenges are more likely for mergers that lead to worse stock market reactions at merger announcements for downstream customer companies (corporate customers or customers henceforth). Unfavorable market reactions are due to higher expected input prices that customer companies

\footnotetext{
${ }^{1}$ Wood and Anderson (1993) review U.S. antitrust policies and processes. U.S. antitrust laws include the 1890 Sherman Act, the 1914 Clayton Act, the 1914 Federal Trade Commission Act, the 1936 Robinson-Patman Act, the 1950 CellerKefauver Act, the 1974 Antitrust Procedures and Penalties Act, the 1976 Hart-Scott-Rodino (HSR) Antitrust Improvements Act, and other minor modifications that strengthen the Clayton Act. Despite minor modifications, the core of U.S. antitrust legislation has remained since the early 1900s, with Section 7 of the Clayton Act being the principal antitrust law regulating business combinations.

${ }^{2}$ Related literature includes Long, Schramm, and Tollison (1973), Ellert (1976), Stillman (1983), Wier (1983), Eckbo and Wier (1985), Johnson and Parkman (1991), Eckbo (1992), Wood and Anderson (1993), Bittlingmayer and Hazlett (2000), Ghosal and Gallo (2001), Aktas, de Bodt, and Roll (2004, 2007), Feinberg and Reynolds (2010), Ghosal (2011), Duso, Neven, and Röller (2007), and Duso, Gugler, and Yurtoglu (2011).
} 
cannot entirely switch away from or pass on to end users (Eckbo, 1983; Fee and Thomas, 2004). We label this the consumer protection hypothesis.

Second, foreign competition increases the supply elasticity of a domestic industry and makes it more difficult to monopolize. Katics and Petersen (1994) show that strong import competition squeezes profit margins and induces domestic companies to merge in order to compete on improved efficiency. Mitchell and Mulherin (1996) find that increased import pressure promotes merger waves in the domestic market to improve efficiency. We hypothesize that, with strong foreign competition (measured by the import ratio, i.e., a merging industry's total imports divided by its total domestic supply), it is more difficult for merging firms to exercise market power and the authorities are less likely to challenge. We call this the foreign competition hypothesis.

Third, for decades, antitrust agencies have implemented the market concentration doctrine (Eckbo, 1988), which posits that the degree of industry concentration proxies for market power. This positive relation between market concentration and market power is implied by the canonical works of Cournot ([1838] 1927) and Nash (1950), but is challenged by Eckbo (1983). Stigler (1964, 1968) further postulates that companies in more concentrated industries are more likely to collude for anticompetitive purposes because it is easier for them to detect deviation from collusion and impose punishment. Therefore, market concentration forms a base for assessing the potentially anticompetitive effects of a proposed merger (see DOJ/FTC Horizontal Merger Guidelines, 1992, 1997 and 2010). The antitrust agencies divide industries into categories by market concentration thresholds and claim they pay more attention to deals that would result in high industry concentration and that would substantially increase concentration. Therefore, the market concentration hurdle hypothesis predicts a higher likelihood of antitrust intervention in deals that hit a stipulated concentration hurdle criterion.

These three hypotheses assume the antitrust agencies act benignly on behalf of society and make dispassionate decisions. In contrast, Stigler (1971), in his economic theory of regulation, posits that concerned parties can influence antitrust case selection. Baumol and Ordover (1985) postulate that industry rivals actively influence antitrust intervention in relation to mergers. Industry rivals may lobby the antitrust agencies to block efficient mergers to avoid being competitively disadvantaged. Since lobbying is costly, only the most disadvantaged rivals have enough incentive to lobby. These include local rivals that would lose a substantial share of geographical markets, and less specialized rivals that would suffer a greater substitution effect from efficient mergers. We 
hypothesize that when local or less specialized industry rivals suffer more from unfavorable wealth effects at merger announcements, the likelihood of antitrust intervention increases. We label the fourth hypothesis the rival influence hypothesis.

We gather a sample of 393 horizontal mergers announced in the U.S. manufacturing sector between public companies during 1980 and 2009. Each year, the FTC and the DOJ report on competition performance and enforcement activities to Congress in a joint annual report. We study these annual reports and identify 35 challenged deals during our sample period. According to Fee and Thomas (2004), the joint annual report is more accurate than Factiva for identifying challenged deals. We model the antitrust agencies' case selection using probit regressions. The variables of interest are customer and rival wealth effects estimated using the event study methodology, foreign import competition measured by the import ratio, and industry concentration measures based on the Herfindahl-Hirschman index (HHI). We control for a range of deal- and industry-specific variables.

In our probit model of antitrust intervention probability, the wealth effects estimated using stock returns potentially suffer from endogeneity. In particular, the likelihood of intervention affects abnormal announcement returns. A Rivers and Vuong (1988) type test confirms the existence of endogeneity. To address this, we follow Aktas, de Bodt, and Roll $(2004,2007)$ and use an instrumental variable (IV) approach (Greene, 2003; Wooldridge, 2002). Specifically, we regress announcement returns on a set of exogenous variables (details in Section 4.2) and use the fitted values in the probit model.

Our empirical analysis provides no evidence supporting the consumer protection hypothesisthe likelihood of antitrust intervention does not systematically respond to average customers', local customers', or reliant customers' wealth effects. Consistent with the foreign competition hypothesis, we find that the import ratio reduces the likelihood of an antitrust challenge. This evidence is in line with previous studies of Katics and Petersen (1994) and Mitchell and Mulherin (1996) who postulate that import competition constrains market power and forces domestic companies to compete on efficiency, thus generating less demand for antitrust intervention. We also find clear evidence for the market concentration hurdle hypothesis. A horizontal merger has a probability of being challenged that is $18-19 \%$ greater in an industry that hits the market concentration hurdle. This confirms that antitrust agencies follow the market concentration doctrine in selecting intervention cases. 
We also find evidence consistent with the rival influence hypothesis. Specifically, a 10\% decrease in local rivals' wealth effect increases the intervention likelihood by 14\%. Similarly, a 10\% decrease in specialized rivals' wealth effect leads to a $14 \%$ higher intervention likelihood. Baumol and Ordover (1985) argue that rivals may lobby against efficient mergers to avoid being competitively disadvantaged. McChesney (1997), Duso (2005) and Tahoun (2014) point out that rivals influence antitrust selection via a variety of mechanisms, e.g., lobbying, campaign contributions, and quid pro quo deals. Bittlingmayer and Hazlett (2000) postulate that antitrust agencies may yield to the influences of concerned parties and deviate from their stated mission. Our results are consistent with these arguments.

We make the following contributions. First, we contribute to the debate on the efficiency of antitrust enforcement. We show that evidence on the efficiency of antitrust enforcement is mixed, contrasting with the conclusion of previous studies that antitrust enforcement is inefficient (Stillman, 1983; Eckbo, 1983, 1988, 1992; Eckbo and Wier, 1985; Aktas, de Bodt, and Roll, 2004, 2007). Our findings are more in line with Duso, Gugler and Yurtoglu (2011), who find mixed evidence of antitrust efficiency in the European Union (EU). It is efficient for antitrust agencies to consider the effect of foreign import competition and to adhere to the market concentration hurdle criterion (though there are debates over the theoretical grounds for the market concentration doctrine). But it is inefficient for antitrust agencies to fail to respond to the wealth effects of customers in general, and of local or reliant customers, or to be captured by interest (rival) groups. Second, to our knowledge, there is no study in the literature that explicitly models the U.S. government's decision process for regulating horizontal mergers. Prior literature on antitrust enforcement considers the intensity of aggregate enforcement (Long, Schramm, and Tollison, 1973; Wood and Anderson, 1993; Feinberg and Reynolds, 2010; Ghosal, 2011) or focuses on particular cases (Bittlingmayer and Hazlett, 2000). ${ }^{3}$ Third, our results show how the wealth effects of interest (rival) groups affect the likelihood of antitrust challenge, which relates to the literature on the demand for regulation to protect vested interests (e.g., Baron, 1998; Posner, 2013).

\footnotetext{
${ }^{3}$ In terms of data structure and research areas, the four papers most related to ours are Aktas, de Bodt, and Roll (2004, 2007), Duso, Neven, and Röller (2007), and Duso, Gugler, and Yurtoglu (2011). Aktas, de Bodt, and Roll (2004) study the market response to European regulation of business combinations, while Aktas, de Bodt, and Roll (2007) explore whether European merger control is protectionist. Duso, Neven, and Röller (2007) investigate the determinants of European Union (EU) merger control decisions, focusing on factors in the institutional and political environment. Duso, Gugler, and Yurtoglu (2011) examine the effectiveness of European merger control, focusing more on detailed merger control procedures. But these four studies focus on EU mergers and their impacts within merging industries, and none covers other firms along the supply chain.
} 
The remainder of the paper continues as follows. Section 2 reviews the relevant literature and develops hypotheses. Section 3 describes the sample and the construction of variables. Section 4 reports univariate and multivariate results. Section 5 summarizes and concludes.

\section{Literature review and hypothesis development}

\subsection{The consumer protection hypothesis}

The antitrust agencies claim that the main aim of antitrust intervention is to protect consumers. FTC former chairman T.J. Muris claims, "The Federal Trade Commission (FTC) works to ensure that the nation's markets are vigorous, efficient and free of restrictions that harm consumers". ${ }^{4}$ This claim is consistent with public interest theories (Pigou, 1932), which suggest that the government should act on behalf of society and intervene when markets fail.

Prior empirical research, however, challenges whether government practices achieve this aim with three pieces of evidence. First, evidence suggests that horizontal mergers on average are motivated by efficiency improvements rather than anticompetitive purposes and most challenged deals would have been benign (Ellert, 1976; Eckbo, 1983; Stillman, 1983; Eckbo and Wier, 1985; Becher, Mulherin, and Walkling, 2012). Eckbo and Wier (1985) conclude that the 1976 HSR Act did not improve the precision of antitrust case selection. Fee and Thomas (2004) and Shahrur (2005) investigate upstream and downstream firms' wealth effects and report non-negative stock price reactions for downstream corporate customers at horizontal deal announcements, suggesting that anticompetitive considerations on average do not drive horizontal mergers. Second, there is at best limited evidence that antitrust regulation deters anticompetitive horizontal mergers. ${ }^{5}$ Eckbo (1992) examines Canadian evidence before 1985 and reports there are few anticompetitive deals for antitrust agencies to deter (until 1985, Canada had a relatively unconstrained legal environment for mergers). Third, some antitrust regulators pursue protectionism, which harms consumers. For instance, EU regulators use antitrust policy to counter foreign bidders and protect domestic firms, even when the proposed deals would have increased consumer welfare (Aktas, de Bodt, and Roll, 2007).

\footnotetext{
${ }^{4}$ A Guide to the Federal Trade Commission, Jan 2002, available on the FTC website, www.ftc.gov.

${ }^{5}$ In one exception, Block and Feinstein (1986) find support for the effective deterrence argument. They examine data on highway construction contracts and the DOJ's actions in this industry over 1975-1982, and find that the DOJ's intensified intervention against bid-rigging reduced subsequent anticompetitive behavior in this industry.
} 
Although suggestive, the above literature does not directly verify that consumer protection is a major concern in antitrust intervention. According to public interest theories (Pigou, 1932), government intervention demands the correct identification of market failures and government always behaves like a dictator on behalf of society. In the context of horizontal mergers, this implies that the antitrust agencies can identify truly anticompetitive deals that harm consumers. Building on the efficient market hypothesis, Eckbo (1983) suggests using the abnormal stock returns to merger related firms to examine this issue. ${ }^{6}$ For instance, corporate customers should have negative abnormal stock returns on the announcement of an anticompetitive deal. Using this approach, we examine the relation between antitrust agencies' case selection and downstream corporate customers' stock market reactions at deal announcement to examine evidence of consumer protection.

Some corporate customers are more vulnerable to anticompetitive upstream consolidation than others. In particular, customers local to the merging firms should be affected more than their distant counterparts due to their dependence on local supply chains. Customers in industries relying more on input from the merging industry should suffer more than those in industries with less input reliance. Antitrust agencies might therefore pay more attention to the impact on these customers. Equally important, since there should be no consumer rights discrimination in the regulatory protection of competition, antitrust agencies should account for the wealth effects of generic customers (i.e., the average customer) in their decisions. The consumer protection hypothesis predicts that antitrust agencies are more likely to challenge deals that harm customers. We therefore hypothesize that the likelihood of intervention increases inversely with the wealth effects of local, reliant, and generic customers.

Hypothesis 1a: A horizontal merger is more likely to face a challenge when the announcement returns to local customers are lower.

Hypothesis 1b: A horizontal merger is more likely to face a challenge when the announcement returns to reliant customers are lower.

Hypothesis 1c: A horizontal merger is more likely to face a challenge when the announcement returns to generic customers are lower.

\footnotetext{
${ }^{6}$ Eckbo (1983) and Stillman (1983) first developed the approach of using stock price reactions to proxy for market expectations about future gains or losses from monopolistic wealth transfers.
} 


\subsection{The foreign competition hypothesis}

Katics and Petersen (1994) posit that pressure from foreign competition has a sizable impact on price-cost margins and challenges domestic-industry efficiency. Mitchell and Mulherin (1996) argue that mergers are often the most effective means for domestic industries to improve efficiency in response to economic shocks such as enhanced foreign competition. Import pressure also increases the supply elasticity of a domestic industry, making it more difficult to monopolize. Therefore, in industries facing greater foreign competition, mergers are less likely to be motivated by anticompetitive rents. This leads to the foreign competition hypothesis.

Hypothesis 2: A horizontal merger is less likely to face a challenge when an industry faces greater foreign competition (as measured by its import ratio).

\subsection{The market concentration hurdle hypothesis}

For decades, the antitrust agencies have focused on increased market concentration when investigating anticompetitive behavior. ${ }^{7}$ Consideration of concentration is involved in many prominent cases. For example, the FTC challenged the proposed merger of Pfizer and Pharmacia announced in 2002, alleging that this merger "... would have substantially lessened competition in the market for the research, development and sale [of several medicines] in the United States" and that "... the markets for the research, development, manufacture and sale of [several medicines] were highly concentrated. The loss of Pharmacia as an independent competitor would have likely resulted in higher prices for consumers" (FTC/DOJ Annual Report to Congress, Fiscal Year 2003, p.17). The DOJ showed concern over market concentration in their antitrust intervention. They challenged General Dynamics' acquisition of Newport News, announced in 2001, alleging that since these two firms "were the only manufacturers of nuclear submarines", this deal "would eliminate competition for nuclear submarines - a weapon platform of vital importance to the security of the United States - resulting in a monopoly" (FTC/DOJ Annual Report to Congress, Fiscal Year 2002, p.9).

Since the DOJ's 1982 Merger Guidelines, the agencies have used the HHI to measure market concentration. The 1992 DOJ/FTC Horizontal Merger Guidelines classifies several thresholds of levels and changes in industry concentration for a horizontal merger: unconcentrated industries

\footnotetext{
${ }^{7}$ For the evolution of U.S. horizontal merger guidelines, see Pittman's presentation in 2012, available at http://www.consiliulconcurentei.ro/en/docs/178/7457/mr-russell-pittman_presentation_the-evolution-of-the-ushorizontal-merger-guidelines.html.
} 
(HHI less than 1000), moderately concentrated industries (HHI between 1000 and 1800), and concentrated industries (HHI greater than 1800). ${ }^{8}$ The antitrust agencies pay more attention if a) firms merge in a concentrated industry and the merger would cause a change in HHI greater than 50 , or b) firms merge in a moderately concentrated industry and the merger would cause a change in HHI greater than 100. These thresholds remained unchanged for 18 years until a revision in 2010.

The focus on market concentration is an application of the market concentration doctrine. As Eckbo (1988) explains, the market concentration doctrine rests on oligopoly models originating with Cournot ([1838] 1927) and Nash (1950), which posit that the level of market power that merging firms can achieve relates to industry concentration, which can then proxy for potential monopoly rents. As aforementioned, Stigler (1968) also suggests that it is easier for firms to collude in a more concentrated industry for anticompetitive purposes, because they can more easily monitor and punish deviation from collusion. These arguments together explain the antitrust agencies' position that firms are more likely to merge for anticompetitive reasons in more concentrated industries.

There are various criticisms of the implementation of the market concentration doctrine, on both theoretical and empirical grounds. Healthy competition rather than anticompetitive intentions may result in industry consolidation as the market reallocates resources to firms that have competitive advantages in responding to change. Further, competitive threats from potential entrants police firms' behavior even in concentrated industries. Therefore, high concentration does not necessarily imply market power (Eckbo, 1988).

The antitrust agencies do not apply the concentration criterion dogmatically. ${ }^{9}$ Instead, they balance multiple concerns such as social welfare, product innovation, and variety of products or service choice. In the 1992 DOJ/FTC Horizontal Merger Guidelines (Section 1.51 of the "General Standards"), the agencies apply a five-step process to assess whether a merger creates market power for merging firms. The guidelines incorporate other criteria, e.g., whether the merger forestalls entry, whether there are alternative ways to obtain the merger efficiency gains, and whether the merger includes a "failing firm". Nevertheless, the market concentration criteria are more straightforward and have formed a base for antitrust intervention (Eckbo, 1988). Therefore, we examine the following hypothesis.

\footnotetext{
${ }^{8}$ The units of HHI in the official guidelines are consistent with U.S. economic census data surveyed by the Bureau of Economic Analysis (BEA). The census-based HHI is the normal HHI (between 0 and 1) multiplied by $10,000$.

${ }^{9}$ Eckbo (1988) cites Rogowsky (1982) as showing that the antitrust agencies intervene in deals that are below guideline thresholds: Rogowsky finds that 20 percent of mergers challenged under the 1968 Merger Guidelines fell below the four-firm market concentration ratio thresholds, and one-third of these violated Section 7 of the Clayton Act.
} 
Hypothesis 3: A horizontal merger is more likely to face a challenge if the deal hits the market concentration hurdle.

\subsection{The rival influence hypothesis}

Stigler (1971) proposes an economic theory of regulation governed by the laws of demand and supply. Demand is from interest groups that anticipate benefits from regulation while the legislature or a regulatory agency delegated by the legislature supplies regulation. The theory implies that regulated firms can influence legislation or regulation for their private benefit. Stigler (1971, p.3) points out that "regulation is acquired by the industry and is designed and operated primarily for its benefits". Previous studies observe that regulated firms collectively use industry regulation to prevent entry (e.g., Slovin, Sushka, and Hudson, 1991). Firms also actively influence legislation or regulation to handicap their competitors. Baron (1998) documents that firms adopt nonmarket means (e.g., providing support to legislators) to influence the stringency of regulation in their favor. By seeking protection from regulators, affected rivals avoid being competitively disadvantaged by efficient mergers. Antitrust guidelines sometimes facilitate such protectionism because the measures that differentiate legitimate competitive behavior from harmful anticompetitive behavior are murky, allowing firms to claim that "almost any successful programme by a rival is 'anticompetitive' and that it constitutes monopolization" (Baumol and Ordover, 1985, p.252).

Evidence from several case studies supports the rival influence argument. Eckbo (1988) documents that Chrysler experienced negative abnormal returns on GM-Toyota's joint venture announcement in 1983, which explains why Chrysler lobbied the FTC to stop the deal. In their study of the Microsoft antitrust case, Bittlingmayer and Hazlett (2000) find that Microsoft's competitors actively promoted antitrust investigations against Microsoft. However, the only finding from large sample studies that is in line with the rival influence argument is from Eckbo (1983) and Eckbo and Wier (1985), who find rivals gain on news of peer mergers being challenged.

Since it is not cost-free to influence antitrust regulation, a rival group chooses to influence only if the expected benefits exceed the costs. Given the impact of a horizontal merger on rivals varies according to rival characteristics, only the most affected rivals have an incentive to influence antitrust case selection. One most affected rival group is local rivals who are likely to be most disadvantaged due to their dependence on local supply chains. Therefore, we hypothesize the following. 
Hypothesis 4a: A horizontal merger is more likely to face a challenge when local rivals have worse announcement returns.

Similarly, efficient horizontal mergers put rivals producing less specialized products in a worse position, as product substitution effects are greater for this group. Sutton (1991) shows that firms invest in R\&D and advertising to attract quality-sensitive consumers, build entry barriers, and become less vulnerable to competition. Hoberg and Phillips (2016) provide empirical evidence that firms producing more specialized products, proxied by increased spending on R\&D and advertising, face reduced competition. Therefore, we form the following hypothesis.

Hypothesis 4b: A horizontal merger is more likely to face a challenge when less specialized rivals have worse announcement returns.

\section{Sample and Data}

\subsection{Sample selection of announced and challenged horizontal mergers}

\subsubsection{Sample selection of horizontal mergers}

We extract all mergers and acquisitions announced between January 1, 1980 and December 31, 2009 from the Securities Data Corporation (SDC) Mergers and Acquisitions database. Ending the sample period in 2009 means that we have a consistent criterion for testing the market concentration hurdle hypothesis. We apply the following screening criteria to form our initial sample of horizontal mergers. First, the bidder does not own a majority stake in the target before the transaction and is seeking to obtain a majority stake or full control through the transaction. This ensures there are effective changes in corporate control. Second, the bidder and target are publicly listed and have data available from the Centre for Research in Security Prices (CRSP) to calculate abnormal returns surrounding the merger announcement. Third, the bidder and target have Compustat data available at both the firm and segment levels, and have in common at least one four-digit SIC segment code. Using four-digit SIC codes to define horizontal mergers is in line with previous research (e.g., Fee and Thomas, 2004; Shahrur, 2005; Bhattacharyya and Nain, 2011). ${ }^{10}$ Fourth, the deal value is no less than \$10 million (in 1980 dollars) to ensure the impacts of mergers are nontrivial. Fifth, transactions are in the manufacturing sector (SIC codes 2000-3999), for which the BEA has a

\footnotetext{
${ }^{10}$ The definition of horizontal mergers based on four-digit segment SICs follows Fee and Thomas (2004). Shahrur (2005) uses historical primary four-digit SICs to define horizontal mergers. Bhattacharyya and Nain (2011) use current primary four-digit SICs to define horizontal mergers. Using their approach to define horizontal mergers leaves our reported results unchanged.
} 
comprehensive coverage of industrial concentration. Ali, Klasa, and Yeung (2009) show that concentration ratios based on Compustat data poorly capture real industry concentration because Compustat covers only public firms. Given the importance of the quality of concentration measures to our study, we trade off sample size for measurement quality and use BEA-based concentration ratios, which include public and private firms in an industry.

We find 393 horizontal mergers announced during 1980-2009 that meet these criteria. In untabulated results, we find that the three Fama-French 49-industries (Fama and French, 1997) with the most merger activity are electronic equipment, pharmaceutical products, and medical equipment, accounting for $51 \%$ of the mergers in our sample. The average ratio of target firm to bidder firm market value of equity is $38 \%$. There are 321 deals (82\%) that are eventually completed.

\subsubsection{Identification of challenged cases}

We define a deal as challenged if the DOJ or the FTC alleges it violates antitrust laws, and documents it in their joint Annual Reports to Congress. Antitrust intervention takes several forms. Some deals attract information requests from the antitrust agencies, and some receive a second request, both of which suggest concerns from the agencies. If concerns are resolved in the information request stage, and a deal is not documented as an antitrust violation in the FTC and DOJ's joint annual report, we do not count it as challenged. We manually check the joint reports for fiscal years 1980 ( $4^{\text {th }}$ report) to 2010 ( $33^{\text {rd }}$ report).$^{11}$ We include the 2010 annual report because investigation decisions are sometimes documented in the year after the deal announcement. In these reports, the antitrust agencies document their antitrust interventions and the outcome of antitrust investigation or litigation. Most cases end up with one of the following three outcomes: a) firms abandon the merger following the complaint; b) firms voluntarily restructure the deal; and c) firms enter into a consent decree or order (usually requiring divestiture, granting, patent licensing, or other remedies) to satisfy regulatory requirements.

Table 1, panel A reports the distribution of antitrust horizontal merger cases over the sample period. ${ }^{12}$ Among the 393 horizontal mergers in our sample, 35 cases are challenged $(9 \%$ of the

\footnotetext{
11 There are 30 reports covering the 31 -year period, 1980-2010. The $10^{\text {th }}$ annual report covers $1986-1987$. These reports are available on the FTC website, www.ftc.gov.

${ }^{12}$ Our count of challenged horizontal deals differs from those in the DOJ and FTC's joint annual reports, for two main reasons. First, we use four-digit SIC codes to gauge product market scope, consistent with Fee and Thomas (2004) and Shahrur (2005), whereas the antitrust agencies use "relevant market", the outer boundary of which is based on cross elasticity of demand. Unfortunately, the components of cross elasticity of demand are not publicly available. Second, we focus on deals between listed firms, whereas the agencies count deals in both the public and private sectors.
} 
sample). The percentage of challenged deals is comparable to existing studies. For example, Fee and Thomas (2004) report 39 public horizontal mergers $(7.04 \%)$ challenged by the DOJ or FTC during 1981-1997. They identify a slightly larger challenged deal sample because their sample includes all industry sectors. Of these 35 challenged deals, 12 are challenged by the DOJ, 23 by the FTC. Considerable heterogeneity is evident in the frequency by year. The years of the Clinton administration 1993-2001 include 54\% of the challenged deals. This is consistent with Ghosal (2011) who finds that the Democrats initiated more civil cases than the Republicans after the antitrust regime shift of U.S. antitrust enforcement in the mid-to-late 1970s, which largely overlaps with our sample period. In panels $\mathrm{B}$ and $\mathrm{C}$, we aggregate challenged deals into four-digit SIC industries and into broader Fama-French 49-industries respectively. The three Fama-French industries with the most challenged deals are pharmaceutical products, chemicals, and food products, accounting for $51 \%$ of the challenged cases in our sample. Appendix 1 lists the challenged deals.

\subsection{Corporate customer and rival identification}

We briefly describe how we identify corporate customers and rivals in this section and describe the related firm portfolio construction process and construction of other key variables in detail in Appendix 2. Appendix 3 defines all the variables.

\subsubsection{Corporate customer identification}

Following Shahrur (2005), we employ the Use table from the BEA Benchmark Input-Output (IO) accounts to identify corporate customers. The Use table is a matrix giving estimates of an industry's dollar value output used by other industries as input for industry pairs. It is compiled and updated periodically. ${ }^{13}$ For each pair of merging industry and one of its customer industries, we calculate a Customer Input Coefficient (CIC) defined as the merging industry's output value purchased by this customer industry divided by the customer industry's total output value. Following previous literature (Shahrur, 2005; Kale and Shahrur, 2007), we drop customer industries with a $C I C$ less than $1 \%$ to ensure the economic relations between customers and the merging industries are nontrivial. We are able to form a generic customer portfolio for each of the 393 deals in our sample. On average, there are 357 (median of 98) customer firms in a generic customer portfolio.

\footnotetext{
${ }^{13}$ The 1982, 1987, 1992, 1997 and 2002 Use tables are available at http://www.bea.gov/industry/io benchmark.htm.
} 
We also identify local and reliant customers, similar to Shahrur (2005). A corporate customer is local if the customer's headquarter locates in either the target's or bidder's headquarter region. ${ }^{14}$ An average local customer portfolio has 120 (median 33) local customers and there are 374 local customer portfolios available for our analysis. A corporate customer is reliant if it operates in the downstream industry with the highest CIC. We are able to construct 284 reliant customer portfolios with an average portfolio having 24 (median 6) reliant customers.

\subsubsection{Industry rival identification}

Following Fee and Thomas (2004), we define a rival firm as one that reports at least one segment in the merging industry in the year before the merger announcement. As Section 1 explains, local and specialized rivals are the two most concerned groups and have the greatest incentive to influence the antitrust agencies. We therefore construct a local and a distant rival portfolio for each deal based on geographical regions. A rival is local if its headquarters is in the same region as either the bidder's or the target's. For an average deal, there are 42 local rivals (median of 17) and 63 distant rivals (median of 33). In a similar fashion, we construct portfolios of specialized and less specialized rivals. We use $R \& D$ and advertising expenses scaled by total assets to measure the degree of specialization. This follows a pool of prior literature (Sutton, 1991; Shaked and Sutton, 1987; Hoberg and Phillips, 2016; Ivanov, Joseph, and Wintoki, 2013; Valta, 2012; Klasa, OrtizMolina, Serfling, and Srinivasan, 2017). Following prior literature, we set advertising expense and $\mathrm{R} \& \mathrm{D}$ expenditure to zero if they are not reported. A rival is specialized if its $\mathrm{R} \& \mathrm{D}$ and advertising expense is in the top quartile of its four-digit industry; otherwise it is less specialized. On average, there are 39 specialized rivals (median of 16) and 73 less specialized rivals (median of 38) for each deal.

We also construct a generic rival portfolio using all rivals and control for its wealth effect in our customer influence regression analysis. On average, we identify 60 rivals (median of 42) for each deal. The wealth effect of the generic rival portfolio is a superior control variable to those of local or less specialized rival portfolios, as it encompasses all rival wealth effects.

We use abnormal returns at deal announcement to these customer and rival portfolios as wealth effect measures in our regression analysis. All these portfolios are equal-weighted (similar to Eckbo,

\footnotetext{
${ }^{14}$ We divide the U.S. domestic market into six regions (Northeast, Southeast, Southwest, Mideast, Midwest, and West) and assign a firm to a region according to its headquarter region. Shahrur (2005) explains that using headquarter location is a better choice than registration location because firms may choose the latter for considerations other than production reasons such as taxation strategy.
} 
1983; Song and Walkling, 2000; Fee and Thomas, 2004; Shahrur, 2005), but value-weighting does not alter our results qualitatively.

\section{Empirical results}

Table 2 presents summary statistics of the variables in our analysis. Panel A reports CARs to merging firms, rivals, and corporate customers for a five-day window, $[-2,2]$, around the deal announcement. On average, the combined $C A R$ is positive $(2.02 \%)$ for the entire sample and for challenged $(1.58 \%)$ and unchallenged $(2.06 \%)$ deals. Bidder firms experience a negative $C A R$ of $-2.59 \%$ while targets have a positive CAR of $23.14 \%$. All of these CARs are significant at $1 \%$, consistent with previous findings (e.g., Eckbo and Wier, 1985; Fee and Thomas. 2004). Overall, horizontal mergers create value for bidders and targets combined. This value increase can be due to anticompetitive rents or efficiency enhancement.

Generic rivals on average have a significant $C A R$ of $0.38 \%$, similar to Eckbo's (1985) findings. ${ }^{15}$ Local rivals and distant rivals on average have CARs of $0.50 \%$ and $0.38 \%$. Less specialized and specialized rivals have $C A R$ s of $0.35 \%$ and $0.43 \%$. All are significant at $5 \%$ or less. But we cannot assert that market power exists based on these rival CARs, as positive rival CARs are consistent with either market power or mergers disseminating positive information about the merging industry (Eckbo, 1988).

Generic customers' $C A R$ is $0.24 \%$ (significant at $5 \%$ ), which suggests mergers in general benefit customers. Challenged mergers drive this positive $C A R$. For unchallenged mergers, the generic customer $C A R$ is a statistically insignificant $0.18 \%$. For the entire sample and the subsamples of challenged and unchallenged mergers, local customers and reliant customers have insignificant $C A R \mathrm{~s}$, which suggests that local and reliant customers, at best, do not benefit from merger efficiency. ${ }^{16}$ With the exception of the generic customer $C A R$, challenged and unchallenged mergers do not exhibit any differences in CARs at conventional significance levels.

An analysis of antitrust case selection should condition on other variables being equal between challenged and unchallenged deals. In panel B, we report summary statistics of other explanatory

\footnotetext{
${ }^{15}$ Eckbo (1985) finds that rivals earn a significant positive $C A R(-3,3)$ of $0.58 \%$. Song and Walkling (2000) report a rival $\operatorname{CAR}(-5,5)$ of $0.56 \%$. Fee and Thomas $(2004)$ report a rival $C A R(-1,1)$ of $0.24 \%$ and Shahrur (2005) reports a rival $\operatorname{CAR}(-2,2)$ of $0.39 \%$.

${ }^{16}$ Shahrur (2005) reports that generic customers in main downstream industries earn a significant positive $C A R(-2,2)$ of $0.30 \%$. Generic customers in dependent downstream industries and local customers in both main and dependent downstream industries on average are unaffected. Fee and Thomas (2004) find that corporate customer $C A R(-1,1)$ is statistically insignificant in their sample.
} 
variables and control variables in our regressions. Compared to unchallenged deals, challenged deals face significantly lower import pressure (Import ratio), induce greater changes in industry concentration ( $\Delta$ Census Herfindahl Index), have greater deal values relative to bidder size (Relative deal size), and are proposed by larger bidders (Ln Bidder Market Cap). We control for these variables in our regressions. We next report the results of our regression analysis.

\subsection{Probit model}

We use probit models to test our hypotheses. Our baseline model to test the consumer protection hypothesis is,

$$
\begin{aligned}
& \operatorname{Pr}(\text { Antitrust challenge })_{j}=\Phi\left(\alpha_{0}+\alpha_{1} \text { Customer } C A R_{j}+\right. \\
& \alpha_{2} \text { Import ratio }_{j}+\alpha_{3} \text { Census hurdle dummy }_{j}+
\end{aligned}
$$

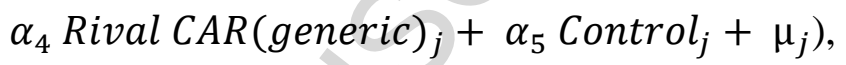

where $\Phi$ is the standard normal cumulative distribution function. Antitrust challenge equals one if the DOJ or the FTC challenges a proposed deal and zero otherwise. Customer CAR is a vector of wealth effects of customer portfolios, including Customer CAR(generic) and either Customer CAR(local) or Customer CAR(reliant). Customer CAR(local), Customer CAR(reliant), and Customer CAR(generic) are the key variables we use to test the consumer protection hypothesis (hypotheses 1a-1c). The consumer protection hypothesis predicts $\alpha_{1}$ to be negative. Rival CAR(generic) controls for overall rival wealth effects. Control represents a vector of control variables. To control for the agencies' concerns related to company size, we control for Relative deal size, Ln Bidder market cap and Census bidder market share. Relative deal size is deal value relative to bidder market capitalization. Ln Bidder market cap is the logarithm of the bidder's market capitalization. Census bidder market share is bidder sales in the merging industry divided by the census total sales of the merging industry. We measure all firm-specific characteristics at the fiscal year-end before the merger announcement. We also include Combined CAR to control for any efficiency or anticompetitive effects due to a merger (Eckbo, Maksimovic, and Williams, 1990; Aktas, de Bodt, and Roll, 2004, 2007). To account for the effects of the economic cycle on antitrust enforcement, we control for Industry growth, calculated as the ratio of the median firm sales of a merging industry the year before a deal announcement to its median firm sales three years before. Amacher, Higgins, Shughart, and Tollison (1985) examine FTC enforcement of the RobinsonPatman Act, and observe that the FTC reduces enforcement when the economy contracts and increases enforcement when the economy expands. Ghosal and Gallo (2001), in contrast, find 
antitrust violations increase during business contractions as firms face pressure to sustain profits. We use median values in the calculation to address the possible bias due to skewness and outliers (Loughran and Ritter, 1997). As a robustness check we also use the growth of merging industries' aggregate sales and obtain similar results. We also control for year dummies in our regressions. Previous studies suggest several additional temporal factors at the macro level that affect antitrust enforcement, e.g., economic and unemployment cycles (Ghosal and Gallo, 2001), the economistattorney ratio in the Antitrust Division (Eisner and Meier, 1990), the budget of the Antitrust Division (Lewis-Beck, 1979), interaction among the president, Congress, and the courts (Wood and Anderson, 1993), and presidency administration and regime shift (Ghosal, 2011). Year dummies capture these effects.

Testing the rival influence hypothesis (hypotheses $4 \mathrm{a}$ and $4 \mathrm{~b}$ ) requires isolating the wealth effects of local and less specialized rivals. These rivals are particularly vulnerable to efficiency gains of merging firms and, as aforementioned, have a greater incentive to influence antitrust intervention. Specifically, we estimate the following two equations.

$$
\begin{aligned}
& \operatorname{Pr}(\text { Antitrust challenge })_{j}=\Phi\left(\alpha_{0}+\alpha_{1} \text { Customer }_{\text {CAR }}+\alpha_{2} \text { Import ratio }_{j}+\right. \\
& \left.\alpha_{3} \text { Census hurdle dummy }{ }_{j}+\alpha_{4} \text { Rival CAR(local }\right)_{j}+
\end{aligned}
$$

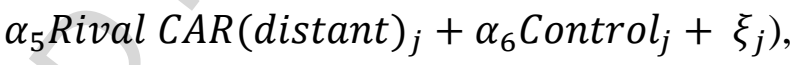

where Rival CAR(local) and Rival CAR(distant) are the wealth effects of local and distant rivals; and

$\operatorname{Pr}(\text { Antitrust challenge })_{j}=\Phi\left(\alpha_{0}+\alpha_{1}\right.$ Customer $C A R_{j}+$

$$
\begin{aligned}
& \alpha_{2} \text { Import ratio }_{j}+\alpha_{3} \text { Census hurdle dummy } \text { dum }+ \\
& \left.\alpha_{4} \text { Rival CAR(less specialized }\right)_{j}+
\end{aligned}
$$

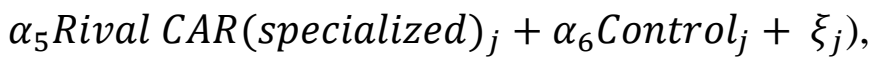

where Rival CAR(less specialized) and Rival CAR(specialized) are the wealth effects of less specialized and specialized rivals. The rival influence hypothesis predicts that $\alpha_{4}$ in both equations is negative.

We include Import ratio and the Census hurdle dummy in equations (1) to (3). The foreign competition hypothesis predicts that $\alpha_{2}$ is negative. The market concentration hurdle hypothesis predicts that $\alpha_{3}$ is positive.

Table 3 presents a correlation matrix of our test variables. Most correlations among independent variables are moderate, with the exceptions of the correlations between Rival CAR(generic) and CARs of rival subgroups, and a 0.75 correlation between Rival CAR(less specialized) and Rival 
$C A R($ distant). Since variation in Rival CAR(generic) is largely captured by the paired CARs of rival subgroups, i.e., Rival CAR(less specialized) and Rival CAR(specialized), and Rival CAR(distant) and Rival CAR(local), we do not include Rival CAR(generic) in equations (2) and (3). Similarly, the high correlation between Rival CAR(less specialized) and Rival CAR(distant) is not a concern as they do not appear in the same regression by design.

\subsection{Endogeneity of measured wealth effects}

An endogeneity issue potentially confounding the estimation is the simultaneity of case selection and related firms' wealth effects. Previous studies (Eckbo, Maksimovic, and Williams, 1990; Aktas, de Bodt, and Roll, 2004, 2007) show that investors can anticipate regulatory activities and announcement wealth effects incorporate this anticipation. In other words, announcement wealth effects reflect both the value consequences of a completed merger and the likelihood of completion.

Similar to Aktas, de Bodt, and Roll (2007), we perform a two-step Rivers and Vuong (1988) type test to check whether endogeneity is a concern in our Probit regressions. In a first step, we instrument the wealth effects with exogenous variables that have no impact on antitrust intervention other than through indirect impacts via the wealth effects. For Combined CAR, we select five instruments, namely Surprise deal dummy, Tender offer dummy, Hostile takeover dummy, Industryadjusted stock payment percentage, and Bidder past performance. For the CARs of rival portfolios, we employ three instruments, namely, Surprise deal dummy, Rival relative size, and Delaware incorporation intensity. For the CARs of customer portfolios, we instrument using Surprise deal dummy, Customer relative size, and Customer dependence. For brevity, Appendix 4 describes the justification for each set of instruments in detail. In a second step, we add the residuals from the

first-stage to Eqs. (1)-(3). An insignificant coefficient on a residual indicates that endogeneity does not significantly bias the un-instrumented probit estimates.

Column 3 of table 4, columns 3 and 8 of table 5, and column 3 of tables 6 and 7 report the endogeneity test results. In table 4, panel A, the coefficient on the first-step regression residuals of Customer CAR(local) is significant, rejecting the null of no endogeneity bias. Similarly, in panel B, the coefficient on the first-step regression residuals of Customer CAR(reliant) also rejects the null of no endogeneity bias. In addition, the endogeneity bias associated with Combined CAR is significant in all specifications. In tables 5-7, these endogeneity bias patterns hold except in panel B of table 7, where the endogeneity bias associated with Customer CAR(reliant) is insignificant. 
We report the IV probit results in the adjacent columns to the endogeneity test results. In table 4, we focus on examining the association between antitrust intervention and the wealth effects of corporate customers. In table 5, we further isolate the wealth effects of sub-group rival CARs. Following Aktas, de Bodt, and Roll (2007), when the bias of an endogenous variable is significant, we substitute its fitted value from the first-stage regression in the second stage probit. Otherwise, we keep the original variable and use its coefficient for statistical inference. For completeness, Appendix 5 presents the first-step regression results. For comparison purposes, tables 4-7 report the un-instrumented probit regression results in the columns before the endogeneity test results.

\subsection{Testing the consumer protection hypothesis}

In table 4, we focus on testing the consumer protection hypothesis (hypotheses 1a-1c). In panel A, we examine the effect of Customer CAR(local) and Customer CAR(generic) in the regressions. Although the probit regression in column 1 gives significant coefficients on both Customer CAR(generic) and Customer CAR(local), this significance pattern changes in the IV probit regression in column 4, which includes the actual values of Customer CAR(generic) and Rival $C A R($ generic), and the fitted value of Customer CAR(local) and Combined CAR. The coefficient on Customer CAR(local) is no longer significant and the coefficient on Customer CAR(generic) is not significant at conventional levels. This result shows that antitrust intervention is not sensitive to the wealth effect of either average customers or local customers, inconsistent with hypotheses 1a and 1c. Table 4, panel B examines the effect of Customer CAR(reliant) and Customer CAR(generic). The IV probit regression includes the actual values of Customer CAR(generic) and Rival CAR(generic), and the fitted values of Customer CAR(reliant) and Combined CAR. The coefficients on Customer CAR(reliant) and Customer CAR(generic) are both insignificant, inconsistent with hypotheses $1 \mathrm{~b}$ and 1c. The un-instrumented probit regression yields similar results. Taken together, these findings show that the antitrust agencies are not systematically concerned about the anticompetitive impact on customers geographically close to the merging firms or customers relying most on the input of the merging firms. Furthermore, they fail to consider the impact on average customers of the merging industry. Given that the wealth effects to local customers, generic customers, or more reliant customers do not systematically affect antitrust case selection, when testing the remaining three hypotheses (the foreign competition hypothesis, the market doctrine hypothesis, and the rival influence hypothesis) in tables 5-7, we control for generic customer CAR only in our main specifications (equations 2 and 3), and report the results in table 5. As a robustness check of 
equations (2) and (3), we report the results of further controlling for local customer CAR in table 6 and for reliant customer CAR in table 7. We base our main interpretation of the three hypotheses on table 5, referring to the results of tables 6 and 7 only when necessary.

\subsection{Testing the foreign competition hypothesis}

Turning to the foreign competition hypothesis (hypothesis 2), Import ratio consistently has a negative coefficient across the specifications in tables 4-7 (significant at 1\% in all specifications). For example, in table 5, column 5, equation (2), the marginal effect of Import ratio is -0.900 , indicating that a $10 \%$ increase in Import ratio reduces the likelihood of an antitrust challenge by $9 \%$. A one standard deviation increase in Import Ratio leads to around a $6 \%$ decrease in the probability of antitrust intervention. Equation (3) gives a similar result for the effect of foreign competition. The marginal effect of Import ratio is -0.910 (table 5, column 10), suggesting that a one standard deviation increase in Import Ratio leads to around a $6.7 \%$ decrease in the probability of antitrust intervention. ${ }^{17}$ This result is consistent with the foreign competition hypothesis. It also echoes the argument of Mitchell and Mulherin (1996) that foreign competition makes an industry more difficult to monopolize and stimulates domestic companies to merge to improve efficiency.

\subsection{Testing the market concentration hurdle hypothesis}

We obtain results clearly consistent with the market concentration hurdle hypothesis (hypothesis 3) in the main specification in tables 4 and 5. On average, hitting the market concentration hurdle leads to an immediate increase in the probability of intervention of $18 \%$ (table 5 , column 5, equation 2) to $19 \%$ (table 5, column 10, equation 3 ). The robustness test results in tables 6 and 7 are mixed: in table 6, the coefficient on Census hurdle dummy is insignificant in the IV probit, while in table 7 Census hurdle dummy has a positive coefficient in both the uninstrumented and IV probits. Overall in tables 4-7, however, Census hurdle dummy has an insignificant coefficient in only two out of eight IV probit specifications. The results overwhelmingly support the market concentration hurdle hypothesis.

We note that academics have been doubtful of the antitrust agencies' heavy reliance on industry concentration. Aktas, de Bodt, and Roll (2007) assert that "The problem, of course, is that the theory behind the ex-ante approach is deeply flawed. As is well known, one can generate a positive relationship between industry concentration and profitability either via a competitive scale-

\footnotetext{
${ }^{17}$ Across all the specifications in tables 6 and 7, the effect of foreign competition remains fairly stable: A one standard deviation increase in Import Ratio leads to around a 5-8\% decrease in the probability of antitrust intervention.
} 
economies argument, or via a monopoly argument" (Aktas, de Bodt, and Roll, 2007, p.1118). Eckbo (1992) also concludes that "the evidence systematically rejects the antitrust doctrine even for values of industry concentration and market shares which, over the past four decades, have been considered crucial in determining the probability that a horizontal merger will have anticompetitive effects" (Eckbo, 1992, p.1028). But, as it is difficult to verify the anticompetitive effect of a horizontal merger (especially before deal completion), it can be costly to precisely identify harmful cases. Reliance on market concentration criteria can be a rational choice by resource constrained antitrust agencies. Wood and Anderson's (1993) survey refers to several resource constraints that antitrust agencies face, including limited budgets and shortages of economists and attorney professionals. This probably explains why, despite heavily criticism of its oversimplification, market concentration remains central to antitrust enforcement.

\subsection{Testing the rival influence hypothesis}

In tables 5-7, we test the rival influence hypothesis (hypotheses $4 \mathrm{a}$ and $4 \mathrm{~b}$ ). Local rivals and less specialized rivals are most likely to be negatively affected by merger efficiency gains. These rivals are therefore most incentivized to incur the costs of influencing antitrust intervention in their favor. In table 5, we add Rival CAR(local) and Rival CAR(distant) to the regressions in columns 1-5, and add Rival CAR(less specialized) and Rival CAR(specialized) to the regressions in columns 6-10, while controlling for the average wealth effect to downstream customers. For robustness, we further control for the wealth effect to local customers and reliant customers, and report these robustness results for Rival CAR(local) and Rival CAR(distant) in table 6, and for Rival CAR(less specialized) and Rival CAR(specialized) in table 7. As section 4.1 explains, since variation in Rival CAR(generic) is largely captured by the twin CARs of rival subgroups, we exclude Rival CAR(generic) from equations (2) and (3). ${ }^{18}$

The endogeneity test in table 5 column 3 shows that Rival CAR(local) and Rival CAR(distant) have insignificant endogeneity biases. We therefore include their actual values in the IV probit in column 4. The coefficient on Rival CAR(local $)$ is $-10.995(z=-3.44)$. The marginal effect indicates that a $10 \%$ decrease in Rival CAR(local) leads to an increase of $14 \%$ in the probability of antitrust intervention. In contrast, Rival CAR(distant) has a coefficient of $10.699(z=1.70)$, insignificant at conventional levels. An interpretation of this insignificant coefficient is that competitive pressure

\footnotetext{
${ }^{18}$ Including the residuals from a regression of Rival CAR(generic) on Rival CAR(local) in equation (2), and the residuals from a regression of Rival CAR(generic) on Rival CAR(less specialized) in equation (3) leaves the reported results unchanged.
} 
due to merging firms' efficiency gains are less likely to affect distant rivals, so they have less incentive to influence intervention. For completeness, we report the un-instrumented probit results in columns 1 and 2. The results are qualitatively similar and the magnitudes of the marginal effects are close to those of the IV probit. The robustness tests in table 6 further confirm our findings. The coefficient on Rival CAR(local) is $-9.110(z=-2.42)$ in panel A and $-12.081(z=-3.08)$ in panel $\mathrm{B}$, both significant at $5 \%$ or better.

The endogeneity test in table 5 column 8 shows that Rival CAR(less specialized) and Rival CAR(specialized) have insignificant endogeneity biases. Therefore, we include their actual values in the IV probit in column 9. In the IV probit regression, Rival CAR(less specialized) has a negative coefficient of $-11.220(z=-1.99)$. The marginal effect suggests that a $10 \%$ decrease in Rival CAR(less specialized) leads to a $14 \%$ increase in the likelihood of a case being challenged. Rival CAR(specialized) has an insignificant coefficient. This is consistent with specialized rivals being better protected from the negative impact of merging firms' efficiency gain, and therefore having less incentive to influence intervention. The robustness test results are mixed: the coefficient on Rival CAR(less specialized) is $-12.402(z=-2.91)$ in table 7 panel A (when further controlling for the local customer wealth effect), confirming the possible influence of less specialized industry competitors on antitrust intervention. The coefficient on Rival CAR(less specialized), however, turns insignificant in table 7 panel B (when further controlling for the reliant customer wealth effect). Overall, in table 5 and table 7, Rival CAR(less specialized) has a significant coefficient in two out of three IV probit specifications, supporting the hypothesis that less specialized industry rivals influence antitrust intervention.

In sum, tables 5-7 provide evidence of greater antitrust protection of most affected rivals. These industry rivals are likely to promote this protection, which is not necessarily socially efficient. This finding differs from that of Duso, Neven, and Röller (2007). Their analysis of European merger control suggests that the European Commission's decisions are not sensitive to firms' interests, including those of industry competitors. As we discuss earlier, there are various ways that concerned rivals can influence the antitrust agencies. For example, local rivals can form a local trade association to exert direct pressure on antitrust agencies, lobby against the deal, or exert indirect influence through campaign contributions (McChesney, 1997) or quid pro quo deals (Tahoun, 2014). Our evidence is consistent with Bittlingmayer and Hazlett's (2000, p.351) observation on the Microsoft antitrust case that, "The May 1998 suit filed by the DOJ was accompanied by a suit filed 
by 20 states. As has been widely observed in the press, these states appear to have been the subject of intense lobbying pressure from locally based computer companies". Our evidence also echoes Posner (1969), who asserts that the FTC's antitrust activities face pressure from Congress, and their investigations are initiated "at the behest of corporations, trade associations, and trade unions whose motivation is at best to shift the costs of their private litigation to the taxpayer and at worst to harass competitors" (Posner, 1969, p.88).

We also obtain some meaningful results for the coefficients on several control variables. The coefficient on Combined CAR is consistently negative in the IV probit regressions in tables 4-7, and significant at conventional levels in most specifications. This suggests a possibility of merging firms influencing the antitrust agencies to clear deals. The coefficient on Relative deal size is consistently positive in the IV probit regressions in tables 4-7, suggesting that antitrust agencies consider the deal's importance to the bidder as an indicator of merger motives. Furthermore, antitrust intervention is positively related to Ln Bidder market cap in most specifications, suggesting that deals from larger bidders are more likely to be challenged. Antitrust agencies may believe that large bidders are more likely to have a greater impact on public interest or will attract more public attention. In addition, the coefficient on Industry growth is insignificant in all specifications. This differs from the countercyclical antitrust litigation argument of Ghosal and Gallo (2001) and from Amacher, Higgins, Shughart, and Tollison's (1985) story of regulators cushioning producer losses in bad times. This may be due to the existence of both effects offsetting in the net effect.

\subsection{Weak instruments}

Appendix 5 reports the first step OLS regressions of the IV probit procedure, columns 1-3 for the wealth effect to customer portfolios, columns 4-8 for the wealth effect to rival portfolios, and column 9 for the combined CAR. The $R^{2}$ s of all first-step OLS regressions are reasonable, being 0.21 for Combined CAR, and 0.09 and above for customer and rival CARs. For Customer CAR(local), Customer CAR(reliant), and Combined CAR, a Fisher test rejects the null hypothesis that all selected exogenous variable coefficients are zero, suggesting our instruments for the wealth effect of local and reliant customers, and merging firms are not weak. The results for generic customer CAR and all rival portfolio CARs are not as good. These estimates are in line with Aktas, de Bodt, and Roll (2007), who identify the source of the weak instrument difficulty to be noisy cumulative abnormal returns. For robustness, we follow Aktas, de Bodt, and Roll (2007) and use a modified version of Anderson and Rubin's (1949) procedure to check whether the inferences from 
our previous tests are valid. The OLS regressions in the first step remain unchanged, but a linear probability model replaces the probit regressions in the second step, with $p$-values estimated by a percentile- $t$ bootstrap (with 2,500 replications) replacing robust $p$-values. ${ }^{19}$ The test results remain qualitatively the same as in tables 4 and 5 with two exceptions: first, the significance of the coefficient on Rival CAR(less specialized) falls to $10 \%$ in table 5; second, the coefficient on Combined CAR turns insignificant in both panels of table 4 and falls to $10 \%$ significance in table 5. Therefore, although some of our instruments are weak, this robustness check indicates that they are still strong enough to support meaningful inference.

\section{Summary and concluding remarks}

What determines antitrust intervention in horizontal mergers? In this paper, we model the decision process of antitrust intervention at the deal level. We formulate four hypotheses based on economic theories and previous literature: the consumer protection hypothesis, the foreign competition hypothesis, the market concentration hurdle hypothesis, and the rival influence hypothesis. We test these hypotheses using a sample of horizontal mergers in the U.S. manufacturing sector announced between 1980 and 2009.

Our results suggest both efficiency and inefficiency in the antitrust intervention process. On the inefficiency side, we find that antitrust enforcement is not consistent with the stated aim of consumer protection. Antitrust agencies do not systematically respond to the wealth effects of customers in general, nor to the wealth effects of local customers or customers in the most reliant downstream industry. We also observe evidence consistent with the hypothesis that certain concerned rival groups can influence antitrust intervention in their favor. These rivals are local and less specialized rivals who are most likely to face pressure from the efficiency gains of merging firms. Our results on rival influence also enrich our understanding of the sources of demand for regulation (Stigler, 1971). On the efficiency side, our results show that, consistent with the foreign competition hypothesis, the likelihood of antitrust intervention decreases with foreign import competition, suggesting that the antitrust agencies are less likely to expend resources to challenge areas where supply elasticity is high, the industry is difficult to monopolize, and mergers are more likely to be motivated by efficiency gains rather than anticompetitive rents. This finding also

\footnotetext{
${ }^{19}$ According to Wooldridge (2002), this procedure approximates the second step qualitative dependent model and generates robust estimates.
} 
highlights the importance of maintaining an open market to contain the detrimental consequence of monopolization on consumers. We also find evidence for the market concentration hurdle hypothesis, suggesting that the authorities effectively implement the concentration hurdle rules contained in the Horizontal Merger Guidelines. The prior literature provides no evidence on the determinants of antitrust intervention at the deal level. Our study fills this gap. Our findings can be a useful reference for calibrating the efficiency of antitrust regulation and enforcement. 


\section{References}

Agrawal, A., Jaffe, J.F., 2000. The post-merger performance puzzle. Advances in Mergers and Acquisitions 1, 7-41.

Ahern, K.R., 2012. Bargaining power and industry dependence in mergers. Journal of Financial Economics 103, 530-550.

Ali, A., Klasa, S., Yeung, E., 2009. The limitations of industry concentration measures constructed with Compustat data: implications for finance research. Review of Financial Studies 22, 3839-3871.

Aktas, N., de Bodt, E., Roll, R., 2004. Market response to European regulation of business combinations. Journal of Financial and Quantitative Analysis 39, 731-757.

Aktas, N., de Bodt, E., Roll, R., 2007. Is European M\&A regulation protectionist? Economic Journal 117, 1096-1211.

Amacher, R.C., Higgins, R.S., Shughart II, W.F., Tollison, R.D., 1985. The behavior of regulatory activity over the business cycle: An empirical test. Economic Inquiry 23, 7-19.

Baron, D., 1998. Integrated market and nonmarket strategies in client and interest group politics. Stanford Graduate School of Business Working Paper.

Baumol, W., Ordover, J., 1985. Use of antitrust to subvert competition. Journal of Law and Economics 28, 247-266.

Becher, D.A., Mulherin, J.H., Walkling, R.A., 2012. Sources of gains in corporate mergers: Refined tests from a neglected industry. Journal of Financial and Quantitative Analysis 47, $57-89$.

Bhattacharyya, S., Nain, A., 2011. Horizontal acquisitions and buying power: A product market analysis. Journal of Financial Economics 99, 97-115.

Bittlingmayer, G., Hazlett, T.W., 2000. DOS Kapital: Has antitrust action against Microsoft created value in the computer industry? Journal of Financial Economics 55, 329-359.

Block, M.K., Feinstein, J.S., 1986. The spillover effect of antitrust enforcement. The Review of Economics and Statistics 68, 122-31.

Bradley, M., Desai, A., Kim, E., 1988. Synergistic gains from corporate acquisitions and their division between the stockholders of target and acquiring firms. Journal of Financial Economics 21, 3-40. 
Bruner, R.F., 2004. Applied Mergers and Acquisitions (University edition). Wiley Finance: New Jersey.

Cournot, A.A., [1838] 1927. Researches into the Mathematical Principles of the Theory of Wealth. Macmillan: New York.

Duso, T., 2005. Lobbying and regulation in a political economy: Evidence from the U.S. Cellular Industry. Public Choice 122, 251-276.

Duso, T., Neven, D.J., Röller, L., 2007. The Political economy of European merger control: Evidence using stock market data. Journal of Law and Economics 50, 455-489.

Duso, T., Gugler, K., Yurtoglu, B.B., 2011. How effective is European merger control. European Economic Review 55, 980-1006.

Eckbo, B.E., 1983. Horizontal mergers, collusion, and stockholder wealth. Journal of Financial Economics 11, 241-271.

Eckbo, B.E., 1985. Mergers and the Market Concentration Doctrine: Evidence from the capital market. The Journal of Business 58, 325-349.

Eckbo, B.E., Wier, P., 1985. Antimerger policy under the Hart-Scott-Rodino Act: A reexamination of the market power hypothesis. Journal of Law and Economics 28, 119-149.

Eckbo, B.E., 1988. Competition and wealth effects of mergers. In F. Mathewson, M. Trebilcock and M. Walker, eds. (1990): The Law and Economics of Competition Policy, chapter 9, 297-332. The Fraser Institute: Vancouver.

Eckbo, B.E., 1992. Mergers and the value of antitrust deterrence. Journal of Finance 47, 10051029.

Eckbo, E., Maksimovic, V., Williams, J., 1990. Consistent estimation of cross-sectional models in event studies. Review of Financial Studies 3, 343-65.

Eckbo, B.E., Makaew, T., Thorburn, K.S., 2014. Are stock-financed takeovers opportunistic? Tuck at Dartmouth Working Paper.

Eisner, M.A., Meier, K.J., 1990. Presidential control versus bureaucratic power: Explaining the Reagan revolution in antitrust. American Journal of Political Science 34, 269-87.

Ellert, J.C., 1976. Mergers, antitrust law enforcement and stockholder returns. Journal of Finance 31, 715-732.

Fan, J.P.H., Lang, L.H.P., 2000. The measurement of relatedness: an application to corporate diversification. Journal of Business 73, 629-660. 
Fee, C.E., Thomas, S., 2004. Sources of gains in horizontal mergers: evidence from customer, supplier, and rival firms. Journal of Financial Economics 74, 423-460.

Feinberg, R.M., Reynolds, K.M., 2010. The determinants of state-level antitrust activity. Review of Industrial Organization 37, 179-196.

Gaughan, P.A., 2015. Mergers, Acquisitions, and Corporate Restructurings. Wiley: New Jersey.

Ghosal, V., and Gallo, J., 2001. The cyclical behaviour of the Department of Justice's antitrust enforcement activity. International Journal of Industrial Organization 19, 27-54.

Ghosal, V., 2011. Regime shift in antitrust laws, economics and enforcement. Journal of Competition Law and Economics 7, 733-774.

Giroud, X., Mueller, H., 2010. Does corporate governance matter in competitive industries? Journal of Financial Economics 95, 312-331.

Greene, W.H., 2003. Econometric Analysis. Upper Saddle River, NJ: Prentice Hall.

Hansen, R., 1987. A theory for the choice of exchange medium in mergers and acquisitions. Journal of Business 60, 75-95.

Hoberg, G., Phillips, G., 2016. Text-based network industries and endogenous product differentiation. Journal of Political Economy 124, 1423-1465.

Ivanov, V., Joseph, K., Wintoki, M.B., 2013. Disentangling the market value of customer satisfaction: Evidence from market reaction to the unanticipated component of ACSI announcements. International Journal of Research in Marketing 30, 168-178.

Johnson, R.N., Parkman, A.M., 1991. Premerger notification and the incentive to merge and litigate. Journal of Law, Economics, \& Organization 7, 145-162.

Kale, J.R., Shahrur, H.K., 2007. Corporate capital structure and the characteristics of suppliers and customers. Journal of Financial Economics 83, 321-365.

Katics, M.M., Petersen, B.C., 1994. The effect of rising import competition on market power: A panel data study of US manufacturing. Journal of Industrial Economics 42, 277-286.

Klasa, S., Ortiz-Molina, H., Serfling, M.A., Srinivasan, S., 2017. Protection of trade secrets and capital structure decisions. Working Paper.

Long, W.F., Schramm, R., Tollison, R., 1973. The economic determinants of antitrust activity. Journal of Law and Economics 16, 351-363.

Loughran, T., Ritter, J., 1997. The operating performance of firms conducting seasoned equity offerings. Journal of Finance 52, 1823-1850. 
McChesney, F., 1997. Money for Nothing: Politicians, Rent Extraction, and Political Extortion. Harvard University Press: Cambridge.

Mitchell, M.L., Mulherin, J.H., 1996. The impact of industry shocks on takeover and restructuring activity. Journal of Financial Economics 41, 193-229.

Nash, J.F., 1950. Equilibrium points in N-person games. Proceedings of the National Academy of Sciences of the U.S.A. 36, 48-49.

Pigou, A.C., 1932. The Economics of Welfare (4th ed.). Macmillan: London.

Posner, R.A., 1969. The federal trade commission. University of Chicago Law Review 37, 47-89.

Posner, R.A., 2013. The concept of regulatory capture: a short, inglorious history. In D. Carpenter and D.A. Moss (eds), Preventing Regulatory Capture: Special Interest Influence and How to Limit it. New York: Cambridge University Press, 49-56.

Rhodes-Kropf, M., Robinson, D.T., Viswanathan, S., 2005. Valuation waves and merger activity: The empirical evidence. Journal of Financial Economics 77, 561-603.

Rivers, D., Vuong, Q.H., 1988. Limited information estimators and exogeneity tests for simultaneous probit models. Journal of Econometrics 39, 347-366.

Rogowsky, R.A., 1982. An economic study of anti-merger remedies. PhD dissertation, University of Virginia.

Schwert, G.W., 2000. Hostility in takeovers: In the eyes of the beholder. Journal of Finance 55, 2599-2640.

Shahrur, H., 2005. Industry structure and horizontal takeovers: Analysis of wealth effects on rivals, suppliers, and corporate customers. Journal of Financial Economics 76, 61-98.

Shaked, A., Sutton, J., 1987. Product differentiation and industrial structure. Journal of Industrial Economics 26, 131-146.

Shivdasani, A., 1993. Board composition, ownership structure, and hostile takeovers. Journal of Accounting and Economics 16, 167-198.

Shleifer, A., Vishny, R.W., 2003. Stock market driven acquisitions. Journal of Financial Economics 70, 295-311.

Slovin, M.B., Sushka, M.E., Hudson, C.D., 1991. Deregulation, contestability, and airline acquisitions. Journal of Financial Economics 30, 231-251.

Song, M.H., Walkling, R.A., 2000. Abnormal returns to rivals of acquisition targets: A test of the “acquisition probability hypothesis”. Journal of Financial Economics 55, 143-171. 
Stigler, G.J., 1964. A theory of oligopoly. Journal of Political Economy 72, 44-61.

Stigler, G.J., 1968. The Organization of Industry. University of Chicago Press: Chicago.

Stigler, G.J., 1971. The theory of economic regulation. Bell Journal of Economics 2, 3-21.

Stillman, R., 1983. Examining antitrust policy towards horizontal mergers. Journal of Financial Economics 11, 225-240.

Streitwieser, M.R., September 2010. Measuring the nation's economy: An industry perspective, a primer on BEA's industry accounts. Bureau of Economic Analysis. http://www.bea.gov/industry/pdf/industry_primer.pdf.

Sutton, J., 1991. Sunk Costs and Market Structure. MIT Press: Cambridge.

Tahoun, A., 2014. The role of stock ownership by US members of Congress on the market for political favors. Journal of Financial Economics 111, 86-110.

Travlos, N.G., 1987. Corporate takeover bids, methods of payment and bidding firms' stock returns. Journal of Finance 42, 943-963.

Valta, P., 2012. Competition and the cost of debt. Journal of Financial Economics 105, 661-682.

Wier, P., 1983. The costs of antimerger lawsuits: Evidence from the stock market. Journal of Financial Economics 11, 207-224.

Wood, B.D., Anderson, J.E., 1993. The politics of U.S. antitrust regulation. American Journal of Political Science 37, 1-39.

Wooldridge, J.M., 2002. Econometric Analysis of Cross Section and Panel Data. The MIT Press. 
Table 1

Sample description

Challenged and unchallenged horizontal public mergers in the U.S. manufacturing sector, 1980-2009. The sample of mergers is from the SDC, with data available on CRSP and Compustat. A horizontal merger is between two firms with at least one overlapping four-digit SIC segment. A challenged merger is a merger challenged by the DOJ or FTC, and recorded in the FTC and DOJ's joint "Annual Report to Congress Pursuant to Subsection (j) of Section 7A of the Clayton Act Hart-Scott-Rodino Antitrust Improvements Act of 1976". Panel A reports the frequencies by year and by antitrust agency, i.e., the DOJ and FTC. Panels B and C report the frequencies of challenged mergers by four-digit SIC and Fama-French 49 industries. Appendix 1 lists the challenged deals.

Panel A: Challenged and unchallenged horizontal mergers by year

\begin{tabular}{|c|c|c|c|c|c|c|c|c|}
\hline \multirow[t]{3}{*}{ Year } & \multicolumn{2}{|c|}{ Announced mergers } & \multicolumn{4}{|c|}{ Challenged mergers } & \multicolumn{2}{|c|}{ Unchallenged mergers } \\
\hline & & & DOJ & FTC & & & & \\
\hline & Freq. & $\%$ & Freq. & Freq. & Freq. & $\%$ & Freq. & $\%$ \\
\hline 1980 & 2 & 0.51 & 0 & 0 & 0 & 0.00 & 2 & 0.56 \\
\hline 1981 & 5 & 1.27 & 0 & 0 & 0 & 0.00 & 5 & 1.40 \\
\hline 1982 & 7 & 1.78 & 0 & 2 & 2 & 5.71 & 5 & 1.40 \\
\hline 1983 & 3 & 0.76 & 0 & 1 & 1 & 2.86 & 2 & 0.56 \\
\hline 1984 & 8 & 2.04 & 1 & 0 & 1 & 2.86 & 7 & 1.96 \\
\hline 1985 & 10 & 2.54 & 0 & 0 & 0 & 0.00 & 10 & 2.79 \\
\hline 1986 & 8 & 2.04 & 0 & 0 & 0 & 0.00 & 8 & 2.23 \\
\hline 1987 & 1 & 0.25 & 0 & 0 & 0 & 0.00 & 1 & 0.28 \\
\hline 1988 & 5 & 1.27 & 0 & 0 & 0 & 0.00 & 5 & 1.40 \\
\hline 1989 & 10 & 2.54 & 0 & 0 & 0 & 0.00 & 10 & 2.79 \\
\hline 1990 & 2 & 0.51 & 0 & 0 & 0 & 0.00 & 2 & 0.56 \\
\hline 1991 & 6 & 1.53 & 0 & 0 & 0 & 0.00 & 6 & 1.68 \\
\hline 1992 & 1 & 0.25 & 0 & 0 & 0 & 0.00 & 1 & 0.28 \\
\hline 1993 & 2 & 0.51 & 0 & 0 & 0 & 0.00 & 2 & 0.56 \\
\hline 1994 & 13 & 3.31 & 0 & 2 & 2 & 5.71 & 11 & 3.07 \\
\hline 1995 & 20 & 5.09 & 1 & 1 & 2 & 5.71 & 18 & 5.03 \\
\hline 1996 & 17 & 4.33 & 0 & 1 & 1 & 2.86 & 16 & 4.47 \\
\hline 1997 & 25 & 6.36 & 0 & 1 & 1 & 2.86 & 24 & 6.70 \\
\hline 1998 & 33 & 8.40 & 1 & 1 & 2 & 5.71 & 31 & 8.66 \\
\hline 1999 & 45 & 11.45 & 1 & 5 & 6 & 17.14 & 39 & 10.89 \\
\hline 2000 & 29 & 7.38 & 3 & 0 & 3 & 8.57 & 26 & 7.26 \\
\hline 2001 & 19 & 4.83 & 0 & 2 & 2 & 5.71 & 17 & 4.75 \\
\hline 2002 & 8 & 2.04 & 1 & 1 & 2 & 5.71 & 6 & 1.68 \\
\hline 2003 & 20 & 5.09 & 1 & 0 & 1 & 2.86 & 19 & 5.31 \\
\hline 2004 & 14 & 3.56 & 0 & 1 & 1 & 2.86 & 13 & 3.63 \\
\hline 2005 & 19 & 4.83 & 1 & 2 & 3 & 8.57 & 16 & 4.47 \\
\hline 2006 & 15 & 3.82 & 1 & 0 & 1 & 2.86 & 14 & 3.91 \\
\hline 2007 & 20 & 5.09 & 1 & 0 & 1 & 2.86 & 19 & 5.31 \\
\hline 2008 & 13 & 3.31 & 0 & 0 & 0 & 0.00 & 13 & 3.63 \\
\hline 2009 & 13 & 3.31 & 0 & 3 & 3 & 8.57 & 10 & 2.79 \\
\hline Total & 393 & 100 & 12 & 23 & 35 & 100 & 358 & 100 \\
\hline
\end{tabular}


Table 1 (continued)

Panel B: Challenged horizontal merger distribution by SIC industry

\begin{tabular}{|c|c|c|c|}
\hline SIC & SIC Industry & Freq. & $\%$ \\
\hline 2011 & Meat Packing Plants & 1 & 2.86 \\
\hline 2026 & Fluid Milk & 1 & 2.86 \\
\hline 2041 & Flour and Other Grain Mill Products & 1 & 2.86 \\
\hline 2051 & Bread and Other Bakery Products, Except Cookies and Crackers & 1 & 2.86 \\
\hline 2621 & Paper Mills & 1 & 2.86 \\
\hline 2834 & Pharmaceutical Preparations & 9 & 25.71 \\
\hline 2836 & Biological Products, Except Diagnostic Substances & 1 & 2.86 \\
\hline 2844 & Perfumes, Cosmetics, and Other Toilet Preparations & 1 & 2.86 \\
\hline 2851 & Paints, Varnishes, Lacquers, Enamels, and Allied Products & 1 & 2.86 \\
\hline 2869 & Industrial Organic Chemicals, Not Elsewhere Classified & 1 & 2.86 \\
\hline 2873 & Nitrogenous Fertilizers & 1 & 2.86 \\
\hline 2899 & Chemicals and Chemical Preparations, Not Elsewhere Classified & & 2.86 \\
\hline 2911 & Petroleum Refining & 3 & 8.57 \\
\hline 3312 & Steel Works, Blast Furnaces \& Rolling Mills (Coke Ovens) & 1 & 2.86 \\
\hline 3357 & Drawing and Insulating of Nonferrous Wire & 1 & 2.86 \\
\hline 3674 & Semiconductors and Related Devices & 1 & 2.86 \\
\hline 3728 & Aircraft Parts and Auxiliary Equipment, Not Elsewhere Classif & 1 & 2.86 \\
\hline 3731 & Ship Building and Repairing & 3 & 8.57 \\
\hline 3812 & $\begin{array}{l}\text { Search, Detection, Navigation, Guidance, Aeronautical, and Naut } \\
\text { Systems and Instruments }\end{array}$ & 2 & 5.71 \\
\hline 3841 & Surgical and Medical Instruments and Apparatus & 2 & 5.71 \\
\hline 3845 & Electromedical and Electrotherapeutic Apparatus & 1 & 2.86 \\
\hline Total & & 35 & 100 \\
\hline \multicolumn{4}{|c|}{ Panel C: Challenged horizontal merger distribution by Fama-French 49 industries } \\
\hline \multicolumn{2}{|c|}{ Fama-French 49 industries } & Freq. & $\%$ \\
\hline \multicolumn{2}{|c|}{ Pharmaceutical Products } & 10 & 28.57 \\
\hline \multicolumn{2}{|c|}{ Chemicals } & 4 & 11.43 \\
\hline \multicolumn{2}{|c|}{ Food Products } & 4 & 11.43 \\
\hline \multicolumn{2}{|c|}{ Electronic Equipment } & 3 & 8.57 \\
\hline \multicolumn{2}{|c|}{ Medical Equipment } & 3 & 8.57 \\
\hline \multicolumn{2}{|c|}{ Petroleum and Natural Gas } & 3 & 8.57 \\
\hline \multicolumn{2}{|c|}{ Shipbuilding, Railroad Equipment } & 3 & 8.57 \\
\hline \multicolumn{2}{|c|}{ Steel Works Etc. } & 2 & 5.71 \\
\hline \multicolumn{2}{|c|}{ Aircraft } & 1 & 2.86 \\
\hline \multicolumn{2}{|c|}{ Consumer Goods } & 1 & 2.86 \\
\hline \multicolumn{2}{|c|}{ Business Supplies } & 1 & 2.86 \\
\hline \multicolumn{2}{|l|}{ Total } & 35 & 100 \\
\hline
\end{tabular}


Table 2

Descriptive statistics

Summary statistics of variables in the regression analysis. Panel A reports abnormal returns to the combined firms, rivals, and customers in challenged and unchallenged horizontal mergers during 1980-2009. Panel B reports the summary statistics of other variables in the regression analysis. Appendix 3 defines all variables. Data are from the Bureau of Economic Analysis (BEA) IO accounts, SDC and Compustat consolidated and industry-segment tapes. The $t$-statistics in parentheses are based on a test for the equality of means. A $t$-test (Ranksum test) tests mean (median) differences of the continuous variables between challenged and unchallenged deals. A Pearson $\chi^{2}$ test tests dummy variable frequency differences between challenged and unchallenged deals. ${ }^{*},{ }^{* *}$, and ${ }^{* * *}$ denote significance at $10 \%, 5 \%$, and $1 \%$.

Panel A: Abnormal returns to the combined firms, rivals, and customers

\begin{tabular}{|c|c|c|c|c|c|c|c|}
\hline \multirow[t]{2}{*}{ Firm portfolio } & \multicolumn{2}{|c|}{ Overall sample } & \multicolumn{2}{|c|}{ Challenged mergers } & \multicolumn{2}{|c|}{ Unchallenged mergers } & \multirow{2}{*}{$\frac{\text { Mean diff. }}{(t \text {-stat })}$} \\
\hline & Mean $(\%)$ & $N$ & Mean $(\%)$ & $N$ & Mean $(\%)$ & $N$ & \\
\hline \multicolumn{8}{|l|}{ Merging firms } \\
\hline Combined firms & $\begin{array}{l}2.015^{* * *} \\
(4.64)\end{array}$ & 393 & $\begin{array}{l}1.580^{* * *} \\
(1.32)\end{array}$ & 35 & $\begin{array}{l}2.057^{* * *} \\
(4.45)\end{array}$ & 358 & $\begin{array}{r}0.477 \\
(0.31)\end{array}$ \\
\hline Bidder & $\begin{array}{l}-2.587^{* * *} \\
(-5.67)\end{array}$ & 393 & $\begin{array}{l}-3.847^{* * *} \\
(-3.12)\end{array}$ & 35 & $\begin{array}{l}-2.463^{\text {*** }} \\
(-5.07)\end{array}$ & 358 & $\begin{array}{l}1.383 \\
(0.86)\end{array}$ \\
\hline Target & $\begin{array}{l}23.144^{* * * *} \\
(18.08)\end{array}$ & 393 & $\begin{array}{l}18.395^{* * *} \\
(4.80)\end{array}$ & 35 & $\begin{array}{l}23.608^{* * *} \\
(17.45)\end{array}$ & 358 & $\begin{array}{c}5.213 \\
(1.16)\end{array}$ \\
\hline \multicolumn{8}{|l|}{ Rivals } \\
\hline Rivals (generic) & $\begin{array}{l}0.382^{* * *} \\
(3.42)\end{array}$ & 393 & $\begin{array}{c}0.289 \\
(0.85)\end{array}$ & & $\begin{array}{l}0.392^{* * * *} \\
(3.31)\end{array}$ & 358 & $\begin{array}{c}0.102 \\
(0.26)\end{array}$ \\
\hline Rivals (local) & $\begin{array}{l}0.503^{* * * *} \\
(3.31)\end{array}$ & 393 & $\begin{array}{c}0.038 \\
(0.09)\end{array}$ & 34 & $\begin{array}{l}0.549^{* * * *} \\
(3.38)\end{array}$ & 349 & $\begin{array}{c}0.511 \\
(0.95)\end{array}$ \\
\hline Rivals (distant) & $\begin{array}{l}0.376^{* * *} \\
(3.02)\end{array}$ & 393 & $\begin{array}{c}0.601 \\
(1.60)\end{array}$ & 34 & $\begin{array}{l}0.355^{* * * *} \\
(2.69)\end{array}$ & 358 & $\begin{array}{c}-0.246 \\
(-0.56)\end{array}$ \\
\hline Rivals (less specialized) & $\begin{array}{l}0.350^{* * *} \\
(2.94)\end{array}$ & 393 & $\begin{array}{c}0.101 \\
(0.29)\end{array}$ & 35 & $\begin{array}{l}0.374^{* * * *} \\
(2.97)\end{array}$ & 357 & $\begin{array}{c}0.273 \\
(0.65)\end{array}$ \\
\hline Rivals (specialized) & $\begin{array}{l}0.426^{* *} \\
(2.57)\end{array}$ & 393 & $0.810^{*}$ & 35 & $\begin{array}{c}0.388^{* * *} \\
(2.20)\end{array}$ & 358 & $\begin{array}{l}-0.422 \\
(-0.73)\end{array}$ \\
\hline Customers & & & & & & & \\
\hline Customers (generic) & $\begin{array}{l}0.244^{* *} \\
(2.16)\end{array}$ & & $\begin{array}{l}0.859^{* *} \\
(2.07)\end{array}$ & 35 & $\begin{array}{c}0.183 \\
(1.57)\end{array}$ & 358 & $\begin{array}{c}-0.676^{*} \\
(-1.71)\end{array}$ \\
\hline Customers (local) & $\begin{array}{c}-0.098 \\
(-0.69)\end{array}$ & 374 & $\begin{array}{l}-0.273 \\
(-0.65)\end{array}$ & 33 & $\begin{array}{c}-0.081 \\
(-0.54)\end{array}$ & 341 & $\begin{array}{c}0.192 \\
(0.38)\end{array}$ \\
\hline Customers (reliant) & $\begin{array}{r}0.236 \\
(0.82)\end{array}$ & 284 & $\begin{array}{r}0.021 \\
(0.02)\end{array}$ & 25 & $\begin{array}{r}0.257 \\
(0.85)\end{array}$ & 259 & $\begin{array}{c}0.236 \\
(0.23)\end{array}$ \\
\hline
\end{tabular}


Table 2 (continued)

Panel B: Summary statistics of other variables in regression analysis

\begin{tabular}{|c|c|c|c|c|c|c|c|c|c|c|c|c|c|c|}
\hline \multirow[b]{2}{*}{ Continuous variable } & \multicolumn{4}{|c|}{ Overall sample } & \multicolumn{4}{|c|}{ Challenged mergers } & \multicolumn{4}{|c|}{ Unchallenged mergers } & \multicolumn{2}{|c|}{$\begin{array}{c}\text { Difference } \\
(p \text {-value })\end{array}$} \\
\hline & Mean & Median & $\begin{array}{l}\text { Std. } \\
\text { dev. }\end{array}$ & $N$ & Mean & Median & $\begin{array}{l}\text { Std. } \\
\text { dev. }\end{array}$ & $N$ & Mean & Median & $\begin{array}{l}\text { Std. } \\
\text { dev. }\end{array}$ & $N$ & Mean & Median \\
\hline Import ratio & 0.184 & 0.177 & 0.114 & 393 & 0.125 & 0.136 & 0.087 & 35 & 0.190 & 0.193 & 0.114 & 358 & 0.00 & 0.00 \\
\hline Census Herfindahl Index & 0.077 & 0.057 & 0.054 & 375 & 0.081 & 0.055 & 0.055 & 33 & 0.077 & 0.057 & 0.053 & 342 & 0.73 & 0.58 \\
\hline$\Delta$ Census Herfindahl Index & 0.072 & 0.001 & 0.260 & 375 & 0.199 & 0.044 & 0.398 & 33 & 0.060 & 0.001 & 0.241 & 342 & 0.00 & 0.00 \\
\hline Industry growth & 1.274 & 1.125 & 0.805 & 389 & 1.145 & 0.883 & 0.769 & 35 & 1.286 & 1.128 & 0.809 & 354 & 0.32 & 0.19 \\
\hline Relative deal size & 0.569 & 0.396 & 0.629 & 393 & 0.739 & 0.610 & 0.624 & 35 & 0.553 & 0.366 & 0.628 & 358 & 0.09 & 0.01 \\
\hline Census bidder market share & 0.302 & 0.061 & 0.593 & 375 & 0.391 & 0.208 & 0.595 & 33 & 0.293 & 0.053 & 0.592 & 342 & 0.37 & 0.00 \\
\hline Ln Bidder market cap & 7.644 & 7.574 & 2.147 & 393 & 8.906 & 8.996 & 1.712 & 35 & 7.520 & 7.438 & 2.147 & 358 & 0.00 & 0.00 \\
\hline $\begin{array}{l}\text { Customer relative size } \\
\text { (generic) }\end{array}$ & 0.030 & 0.004 & 0.085 & 393 & 0.003 & 0.001 & 0.006 & 35 & 0.033 & 0.004 & 0.088 & 358 & 0.05 & 0.00 \\
\hline $\begin{array}{l}\text { Customer relative size } \\
\text { (local) }\end{array}$ & 0.026 & 0.002 & 0.079 & 374 & 0.002 & 0.001 & 0.004 & 33 & 0.028 & 0.003 & 0.082 & 341 & 0.06 & 0.00 \\
\hline $\begin{array}{l}\text { Customer relative size } \\
\text { (reliant) }\end{array}$ & 0.046 & 0.003 & 0.142 & 284 & 0.002 & 0.000 & 0.004 & 25 & 0.051 & 0.003 & 0.148 & 259 & 0.10 & 0.00 \\
\hline $\begin{array}{l}\text { Customer dependence } \\
\text { (generic) }\end{array}$ & 0.052 & 0.037 & 0.043 & 393 & 0.046 & 0.030 & 0.034 & 35 & 0.052 & 0.037 & 0.044 & 358 & 0.45 & 0.66 \\
\hline $\begin{array}{l}\text { Customer dependence } \\
\text { (local) }\end{array}$ & 0.052 & 0.037 & 0.043 & 374 & 47 & 0.030 & 0.034 & 33 & 0.053 & 0.037 & 0.044 & 341 & 0.51 & 0.65 \\
\hline $\begin{array}{l}\text { Customer dependence } \\
\text { (reliant) }\end{array}$ & 0.120 & 0.112 & 0.100 & & 0.128 & 0.133 & 0.100 & 25 & 0.119 & 0.116 & 0.100 & 259 & 0.67 & 0.34 \\
\hline $\begin{array}{l}\text { Rival relative size } \\
\text { (generic) }\end{array}$ & 0.073 & 0.013 & 0.184 & 393 & 0.015 & 0.004 & 0.028 & 35 & 0.079 & 0.014 & 0.191 & 358 & 0.05 & 0.00 \\
\hline $\begin{array}{l}\text { Rival relative size } \\
\text { (local) }\end{array}$ & 0.043 & 0007 & 0.099 & 383 & 0.023 & 0.003 & 0.095 & 34 & 0.045 & 0.009 & 0.099 & 349 & 0.22 & 0.01 \\
\hline $\begin{array}{l}\text { Rival relative size } \\
\text { (distant) }\end{array}$ & 0.088 & 0.012 & 0.258 & 392 & 0.015 & 0.004 & 0.029 & 34 & 0.095 & 0.014 & 0.269 & 358 & 0.08 & 0.00 \\
\hline $\begin{array}{l}\text { Rival relative size } \\
\text { (less specialized) }\end{array}$ & 0.079 & 0.010 & 0.207 & 392 & 0.014 & 0.004 & 0.028 & 35 & 0.085 & 0.012 & 0.216 & 357 & 0.05 & 0.00 \\
\hline $\begin{array}{l}\text { Rival relative size } \\
\text { (specialized) }\end{array}$ & 0.054 & 0.005 & 0.191 & 393 & 0.014 & 0.004 & 0.028 & 35 & 0.058 & 0.006 & 0.199 & 358 & 0.20 & 0.01 \\
\hline $\begin{array}{l}\text { Delaware incorporation } \\
\text { intensity (generic) }\end{array}$ & 0.525 & 0.574 & 0.207 & 393 & 0.549 & 0.612 & 0.258 & 35 & 0.523 & 0.571 & 0.201 & 358 & 0.48 & 0.34 \\
\hline $\begin{array}{l}\text { Delaware incorporation } \\
\text { intensity (local) }\end{array}$ & 0.519 & 0.565 & 0.305 & 393 & 0.498 & 0.600 & 0.326 & 35 & 0.521 & 0.564 & 0.303 & 358 & 0.66 & 0.66 \\
\hline $\begin{array}{l}\text { Delaware incorporation } \\
\text { intensity (distant) }\end{array}$ & 0.457 & 0.500 & 0.265 & 393 & 0.416 & 0.500 & 0.291 & 35 & 0.461 & 0.500 & 0.262 & 358 & 0.34 & 0.69 \\
\hline
\end{tabular}


Table 2 (continued)

\begin{tabular}{|c|c|c|c|c|c|c|c|c|c|c|c|c|c|c|}
\hline \multirow[b]{2}{*}{ Continuous variable } & \multicolumn{4}{|c|}{ Overall sample } & \multicolumn{4}{|c|}{ Challenged mergers } & \multicolumn{4}{|c|}{ Unchallenged mergers } & \multicolumn{2}{|c|}{$\begin{array}{c}\text { Difference } \\
(p \text {-value })\end{array}$} \\
\hline & Mean & Median & $\begin{array}{l}\text { Std. } \\
\text { dev. }\end{array}$ & $N$ & Mean & Median & $\begin{array}{l}\text { Std. } \\
\text { dev. }\end{array}$ & $N$ & Mean & Median & $\begin{array}{l}\text { Std. } \\
\text { dev. }\end{array}$ & $N$ & Mean & Median \\
\hline $\begin{array}{l}\text { Delaware incorporation } \\
\text { intensity (less specialized) }\end{array}$ & 0.490 & 0.545 & 0.238 & 393 & 0.446 & 0.523 & 0.277 & 35 & 0.494 & 0.548 & 0.234 & 358 & 0.26 & 0.40 \\
\hline $\begin{array}{l}\text { Delaware incorporation } \\
\text { intensity (specialized) }\end{array}$ & 0.526 & 0.625 & 0.324 & 393 & 0.617 & 0.750 & 0.368 & 35 & 0.517 & 0.614 & 0.318 & 358 & 0.08 & 0.03 \\
\hline $\begin{array}{l}\text { Industry-adjusted stock } \\
\text { payment percentage }\end{array}$ & 0.001 & 0.000 & 0.023 & 393 & -0.001 & 0.000 & 0.008 & 35 & 0.00 & 0.000 & 0.024 & 358 & 0.52 & 0.38 \\
\hline \multirow[t]{3}{*}{ Bidder past performance } & 0.132 & 0.146 & 0.133 & 393 & 0.168 & 0.164 & 0.083 & 35 & 0.129 & 0.144 & 0.136 & 358 & 0.10 & 0.15 \\
\hline & \multicolumn{4}{|c|}{ Overall sample } & \multicolumn{4}{|c|}{ Challenged mergers } & \multicolumn{4}{|c|}{ Unchallenged mergers } & \multirow{2}{*}{\multicolumn{2}{|c|}{$\begin{array}{l}\text { Mean Diff. } \\
(p \text {-value })\end{array}$}} \\
\hline & \multicolumn{2}{|c|}{ Mean $(\%)$} & & $N$ & \multicolumn{2}{|c|}{ Mean $(\%)$} & & $N$ & \multicolumn{2}{|c|}{ Mean $(\%)$} & \multicolumn{2}{|r|}{$N$} & & \\
\hline Census hurdle dummy & \multicolumn{2}{|l|}{7.20} & & 27 & \multicolumn{2}{|l|}{24.24} & & 8 & \multicolumn{2}{|c|}{5.56} & \multicolumn{2}{|r|}{19} & \multicolumn{2}{|c|}{0.00} \\
\hline Surprise deal dummy & \multicolumn{2}{|l|}{46.82} & & 184 & \multicolumn{2}{|l|}{40.00} & & 14 & \multicolumn{2}{|l|}{47.49} & \multicolumn{2}{|r|}{170} & \multicolumn{2}{|r|}{0.40} \\
\hline Tender offer dummy & \multicolumn{2}{|l|}{29.77} & & 117 & \multirow{2}{*}{\multicolumn{2}{|c|}{$\begin{array}{r}20.00 \\
8.57\end{array}$}} & & 7 & \multicolumn{2}{|l|}{30.73} & \multicolumn{2}{|r|}{119} & \\
\hline Hostile takeover dummy & \multicolumn{2}{|l|}{5.85} & & 23 & & & & 3 & \multicolumn{2}{|l|}{5.59} & \multicolumn{2}{|r|}{20} & \multicolumn{2}{|r|}{$\begin{array}{l}0.19 \\
0.47\end{array}$} \\
\hline
\end{tabular}


Table 3

Correlation coefficients

Correlation matrix for all variables in the main regression models. Appendix 3 gives the definition of all variables.

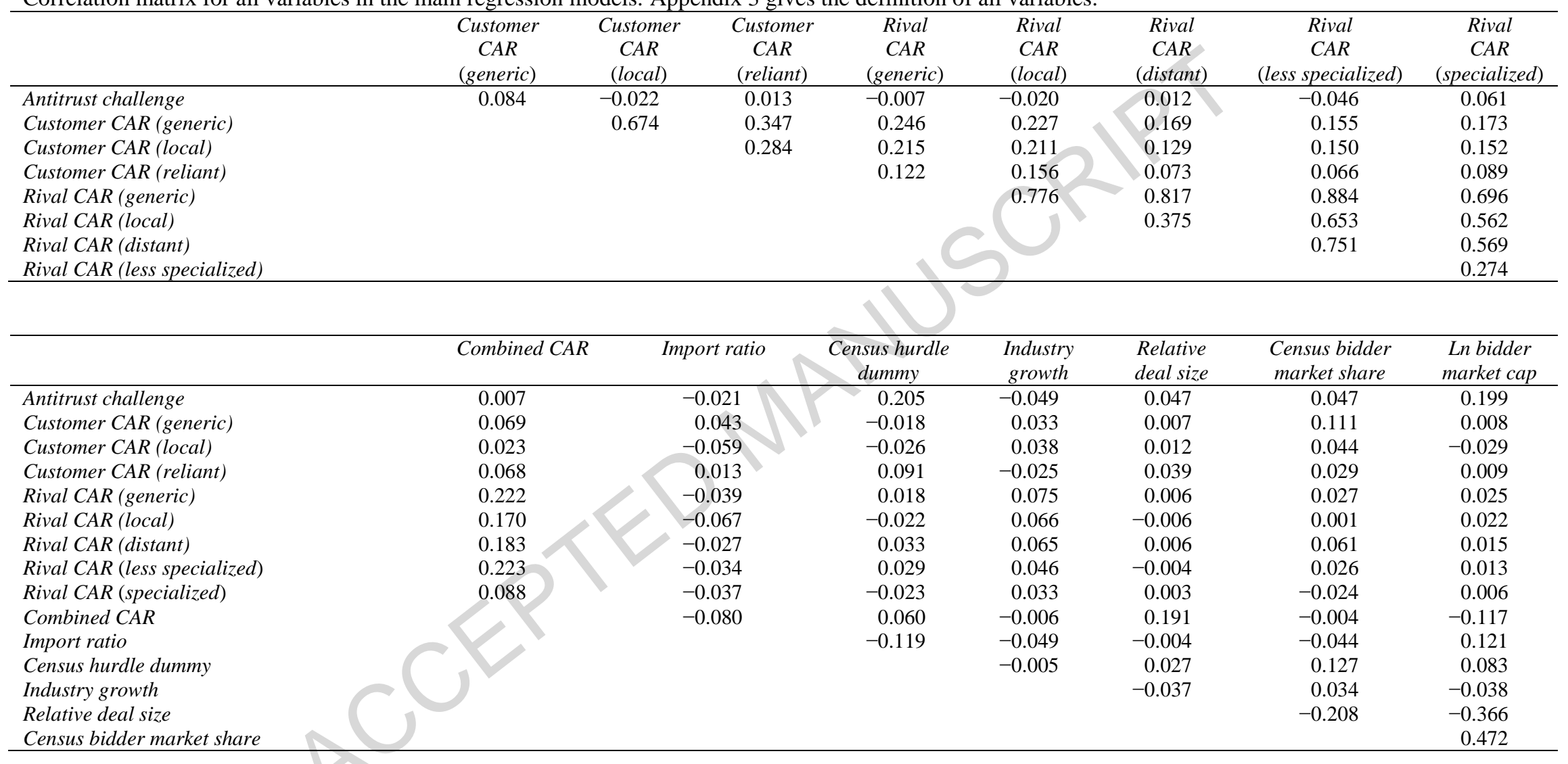


Table 4

\section{The impacts of customer wealth effect, foreign competition, and market concentration hurdle on antitrust case selection}

This table reports the impacts of customer wealth effect, foreign competition, and market concentration hurdle on antitrust case selection. Panel A focuses on the wealth effect impact of local customers, panel B on the wealth effect impact of reliant customers. In both panels, columns 1 and 2 report coefficients and marginal effects of uninstrumented probit regressions. Column 3 reports Rivers and Vuong (1988) endogeneity tests of wealth effect variables. Columns 4 and 5 report coefficients and marginal effects of two-step instrumental variable probit regressions. Residuals and fitted values are from the first-step OLS regressions in Appendix 5. Appendix 3 defines all variables. All variables are winsorized at the $1^{\text {st }}$ and $99^{\text {th }}$ percentiles. $z$-statistics are in parentheses. ${ }^{*},{ }^{* *}$, and ${ }^{* * *}$ denote significance of probit and endogeneity test coefficients at $10 \%, 5 \%$, and $1 \%$.

Panel A: The impact of local customer wealth effect on antitrust case selection

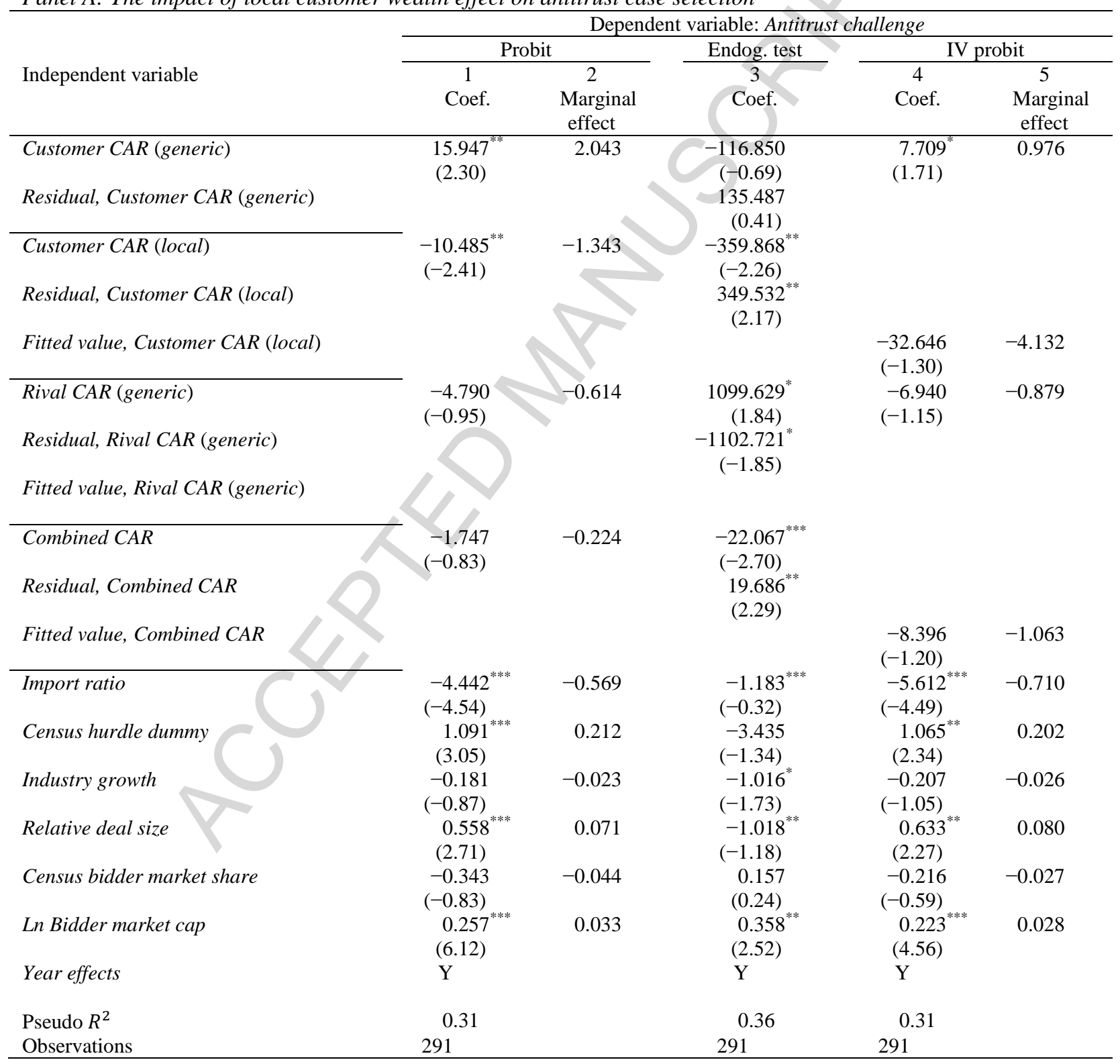


Table 4 (continued)

Panel B: The impact of reliant customer wealth effect on antitrust case selection

\begin{tabular}{|c|c|c|c|c|c|}
\hline \multirow[b]{3}{*}{ Independent Variable } & \multicolumn{5}{|c|}{ Dependent variable: Antitrust challenge } \\
\hline & \multicolumn{2}{|c|}{ Probit } & \multirow{2}{*}{$\begin{array}{c}\text { Endog. test } \\
3 \\
\text { Coef. }\end{array}$} & \multicolumn{2}{|c|}{ IV probit } \\
\hline & $\begin{array}{c}1 \\
\text { Coef. }\end{array}$ & $\begin{array}{c}2 \\
\text { Marginal } \\
\text { effect }\end{array}$ & & $\begin{array}{c}4 \\
\text { Coef. }\end{array}$ & $\begin{array}{c}5 \\
\text { Marginal } \\
\text { effect }\end{array}$ \\
\hline Customer CAR (generic) & $\begin{array}{l}3.317 \\
(0.48)\end{array}$ & 0.475 & $\begin{array}{r}164.016 \\
(0.95)\end{array}$ & $\begin{array}{l}4.378 \\
(0.68)\end{array}$ & 0.602 \\
\hline Residual, Customer CAR (generic) & & & $\begin{array}{r}-161.835 \\
(-0.95)\end{array}$ & & \\
\hline Customer CAR (reliant) & $\begin{array}{r}0.727 \\
(0.24)\end{array}$ & 0.104 & $\begin{array}{c}-84.948^{* *} \\
(-2.04)\end{array}$ & $>$ & \\
\hline Residual, Customer CAR (reliant) & & & $\begin{array}{c}86.666^{* * *} \\
(2.05)\end{array}$ & & \\
\hline Fitted value, Customer CAR (reliant) & & & & $\begin{array}{r}-12.107 \\
(-0.87)\end{array}$ & -1.665 \\
\hline Rival CAR (generic) & $\begin{array}{l}-2.293 \\
(-0.45)\end{array}$ & -0.328 & $\begin{array}{r}216.099 \\
(0.73)\end{array}$ & $\begin{array}{l}-1.592 \\
(-0.29)\end{array}$ & -0.219 \\
\hline Residual, Rival CAR (generic) & & & & & \\
\hline Combined CAR & $\begin{array}{l}-0.692 \\
(-0.28)\end{array}$ & 99 & $\begin{array}{l}-27.926^{* * *} \\
(-3.48)\end{array}$ & & \\
\hline Residual, Combined CAR & & & $\begin{array}{l}27.267^{* * * *} \\
(3.18)\end{array}$ & & \\
\hline Fitted value, Combined CAR & & & & $\begin{array}{c}-17.684^{* *} \\
(-1.96)\end{array}$ & -2.432 \\
\hline Import ratio & $\begin{array}{l}-4.250^{* * *} \\
(-2.94)\end{array}$ & -0.609 & $\begin{array}{l}-7.376^{* *} \\
(-2.40)\end{array}$ & $\begin{array}{l}-7.118^{* * *} \\
(-3.01)\end{array}$ & -0.979 \\
\hline Census hurdle dummy & $\begin{array}{l}0.893^{* *} \\
(2.41)\end{array}$ & 0.178 & $\begin{array}{l}2.593^{* *} \\
(2.24)\end{array}$ & $\begin{array}{l}1.152^{* *} \\
(2.36)\end{array}$ & 0.235 \\
\hline Industry growth & $\begin{array}{l}-0.279 \\
(-1.08)\end{array}$ & -0.040 & $\begin{array}{l}-0.789^{*} \\
(-1.79)\end{array}$ & $\begin{array}{l}-0.269 \\
(-1.41)\end{array}$ & -0.037 \\
\hline Relative deal size & $\begin{array}{l}0.452^{* *} \\
(2.48)\end{array}$ & 0.065 & $\begin{array}{l}1.072^{* *} \\
(2.29)\end{array}$ & $\begin{array}{l}0.777^{* *} \\
(2.42)\end{array}$ & 0.107 \\
\hline Census bidder market share & $\begin{array}{l}-0.152 \\
(-0.58)\end{array}$ & -0.022 & $\begin{array}{l}-0.510 \\
(-0.88)\end{array}$ & $\begin{array}{c}0.080 \\
(0.25)\end{array}$ & 0.011 \\
\hline Ln Bidder market cap & $\begin{array}{l}0.227^{* * *} \\
(4.21)\end{array}$ & 0.032 & $\begin{array}{l}-0.025 \\
(-0.26)\end{array}$ & $\begin{array}{r}0.120 \\
(1.52)\end{array}$ & 0.017 \\
\hline Year effects & Y & & Y & $\mathrm{Y}$ & \\
\hline Pseudo $\mathrm{R}^{2}$ & 0.27 & & 0.33 & 0.30 & \\
\hline Observations & 197 & & 197 & 197 & \\
\hline
\end{tabular}




\section{Table 5}

The impact of rival wealth effect, foreign competition, and market concentration hurdle on antitrust case selection

This table reports the impact of rival wealth effect, foreign competition, and market concentration hurdle on antitrust case selection. It reports the results of Eqs. (2) and (3), controlling for generic customer wealth effect only. Columns 1-5 focus on the impacts of local rivals' wealth effects, columns 6-10 on the impacts of less specialized rivals' wealth effects. Columns 1,2, 6, and 7 report coefficients and marginal effects of un-instrumented probit regressions. Columns 3 and 8 report Rivers and Vuong (1988) endogeneity tests of measures of wealth effect. Columns 4, 5, 9, and 10 report coefficients and marginal effects of two-step instrumental variable probit regressions. Residuals and fitted values are from the first-step OLS regressions in Appendix 5. Appendix 3 defines all variables. All variables are winsorized at the $1^{\text {st }}$ and $99^{\text {th }}$ percentiles. $z$-statistics are in parentheses. ${ }^{*},{ }^{* *}$, and ${ }^{* * * *}$ denote significance of probit and endogeneity test coefficients at $10 \%, 5 \%$, and $1 \%$.

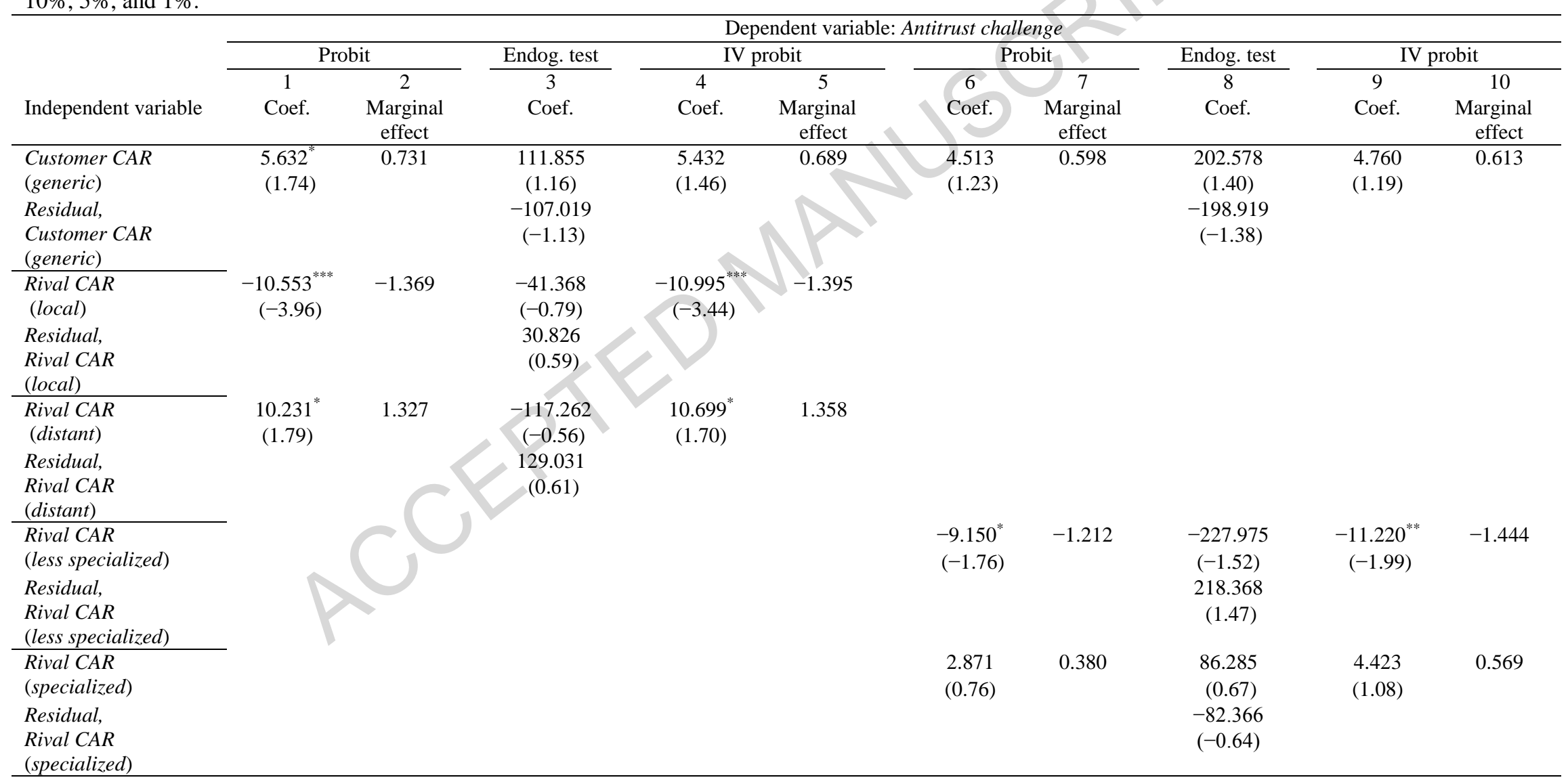




\section{Table 5 (continued)}

\begin{tabular}{|c|c|c|c|c|c|c|c|c|c|c|}
\hline \multirow[b]{4}{*}{ Independent variable } & \multicolumn{10}{|c|}{ Dependent variable: Antitrust challenge } \\
\hline & \multicolumn{2}{|c|}{ Probit } & \multirow{3}{*}{$\begin{array}{c}\text { Endog. test } \\
3 \\
\text { Coef. }\end{array}$} & \multicolumn{2}{|c|}{ IV probit } & \multicolumn{2}{|c|}{ Probit } & \multirow{3}{*}{$\begin{array}{c}\text { Endog. test } \\
8 \\
\text { Coef. }\end{array}$} & \multicolumn{2}{|c|}{ IV probit } \\
\hline & 1 & 2 & & 4 & 5 & 6 & 7 & & 9 & 10 \\
\hline & Coef. & $\begin{array}{c}\text { Marginal } \\
\text { effect }\end{array}$ & & Coef. & $\begin{array}{c}\text { Marginal } \\
\text { effect }\end{array}$ & Coef. & $\begin{array}{c}\text { Marginal } \\
\text { effect }\end{array}$ & & Coef. & $\begin{array}{c}\text { Marginal } \\
\text { effect }\end{array}$ \\
\hline Combined CAR & $\begin{array}{l}-1.640 \\
(-0.79)\end{array}$ & -0.213 & $\begin{array}{c}-20.014^{* * * *} \\
(-3.27)\end{array}$ & & & $\begin{array}{l}-1.043 \\
(-0.51)\end{array}$ & & $\begin{array}{c}-23.143^{* * *} \\
(-3.37)\end{array}$ & & \\
\hline $\begin{array}{l}\text { Residual, } \\
\text { Combined CAR }\end{array}$ & & & $\begin{array}{c}18.897^{* * * *} \\
(2.63)\end{array}$ & & & & & $\begin{array}{l}22.751^{* * * *} \\
(2.75)\end{array}$ & & \\
\hline $\begin{array}{l}\text { Fitted value, } \\
\text { Combined CAR }\end{array}$ & & & & $\begin{array}{c}-17.390^{* * *} \\
(-2.85)\end{array}$ & -2.207 & & & & $\begin{array}{c}-18.678^{* * *} \\
(-2.72)\end{array}$ & -2.404 \\
\hline Import ratio & $\begin{array}{c}-4.564^{* * *} \\
(-4.76)\end{array}$ & -0.592 & $\begin{array}{c}-9.381^{* * *} \\
(-4.58)\end{array}$ & $\begin{array}{c}-7.091^{* * * *} \\
(-5.78)\end{array}$ & -0.900 & $\begin{array}{c}-4.245^{* * *} \\
(-3.90)\end{array}$ & -0.562 & $\begin{array}{c}-6.728^{* *} \\
(-2.19)\end{array}$ & $\begin{array}{c}-7.068^{* * * *} \\
(-4.82)\end{array}$ & -0.910 \\
\hline Census hurdle dummy & $\begin{array}{l}0.917^{* * *} \\
(2.21)\end{array}$ & 0.170 & $\begin{array}{l}1.941 \\
(1.37)\end{array}$ & $\begin{array}{l}0.993^{* *} \\
(2.26)\end{array}$ & 0.181 & $\begin{array}{l}0.921^{* * *} \\
(2.40)\end{array}$ & 0.175 & $\begin{array}{c}1.933^{* * *} \\
(2.59)\end{array}$ & $\begin{array}{l}1.026^{* *} \\
(2.43)\end{array}$ & 0.193 \\
\hline Industry growth & $\begin{array}{l}-0.163 \\
(-0.79)\end{array}$ & -0.021 & $\begin{array}{l}0.054 \\
(0.14)\end{array}$ & $\begin{array}{l}-0.140 \\
(-0.71)\end{array}$ & -0.018 & $\begin{array}{l}-0.117 \\
(-0.65)\end{array}$ & -0.015 & $\begin{array}{l}0.273 \\
(0.96)\end{array}$ & $\begin{array}{l}-0.086 \\
(-0.54)\end{array}$ & -0.011 \\
\hline Relative deal size & $\begin{array}{l}0.581^{* *} \\
(2.48)\end{array}$ & 0.075 & $\begin{array}{c}1.293^{* * *} \\
(3.02)\end{array}$ & $\begin{array}{c}0.866^{* * * *} \\
(2.89)\end{array}$ & 0.110 & $\begin{array}{l}0.527^{* *} \\
(2.34)\end{array}$ & 0.070 & $\begin{array}{c}1.252^{* * *} \\
(3.39)\end{array}$ & $\begin{array}{c}0.837^{* * *} \\
(2.75)\end{array}$ & 0.108 \\
\hline $\begin{array}{l}\text { Census bidder market } \\
\text { share }\end{array}$ & $\begin{array}{l}-0.487 \\
(-1.43)\end{array}$ & -0.063 & $\begin{array}{l}-0.357 \\
(-0.61)\end{array}$ & $\begin{array}{l}-0.317 \\
(-0.80)\end{array}$ & -0.040 & $\begin{array}{l}-0.431 \\
(-1.32)\end{array}$ & -0.057 & $\begin{array}{l}-1.162 \\
(-1.39)\end{array}$ & $\begin{array}{l}-0.229 \\
(-0.59)\end{array}$ & -0.029 \\
\hline Ln Bidder market cap & $\begin{array}{c}0.281^{* * * *} \\
(8.09)\end{array}$ & 0.036 & $\begin{array}{c}0.165^{* * *} \\
(2.50)\end{array}$ & $\begin{array}{c}0.193^{* * * *} \\
(3.57)\end{array}$ & 0.024 & $\begin{array}{c}0.273^{* * * *} \\
(7.49)\end{array}$ & 0.036 & $\begin{array}{l}0.369 \\
(1.60)\end{array}$ & $\begin{array}{c}0.172^{* * *} \\
(3.19)\end{array}$ & 0.022 \\
\hline Year effects & $\mathrm{Y}$ & & & Y & & Y & & $\mathrm{Y}$ & $\mathrm{Y}$ & \\
\hline Pseudo $\mathrm{R}^{2}$ & 0.28 & & 0.31 & 0.30 & & 0.27 & & 0.31 & 0.29 & \\
\hline Observations & 300 & & 300 & 300 & & 300 & & 300 & 300 & \\
\hline
\end{tabular}


Table 6

The impact of local rival and distant rival wealth effects on antitrust case selection (robustness test)

The table reports robustness test results for the impacts of local rival and distant rival wealth effects on antitrust case selection. Panel A controls for local customer wealth effect, while panel B controls for reliant customer wealth effect. In panels A and B, columns 1 and 2 report coefficients and marginal effects of un-instrumented probit regressions. Columns 3 reports Rivers and Vuong (1988) endogeneity tests of measures of the wealth effect. Columns 4 and 5 report coefficients and marginal effects of two-step instrumental variable probit regressions. Residuals and fitted values are from the first-step OLS regressions in Appendix 5. Appendix 3 defines all variables. All variables are winsorized at the $1^{\text {st }}$ and $99^{\text {th }}$ percentiles. $z$-statistics are in parentheses. ${ }^{*},{ }^{* *}$, and ${ }^{* * *}$ denote significance of probit and endogeneity test coefficients at $10 \%, 5 \%$, and $1 \%$.

Panel A: The impact of local rival and distant rival's wealth effects on antitrust case selection (controlling for local customer $C A R$ )

\begin{tabular}{|c|c|c|c|c|c|}
\hline \multirow[b]{3}{*}{ Independent variable } & \multicolumn{5}{|c|}{ Dependent variable: Antitrust challenge } \\
\hline & \multicolumn{2}{|c|}{ Probit } & \multirow{2}{*}{$\begin{array}{c}\text { Endog. test } \\
3 \\
\text { Coef. }\end{array}$} & \multicolumn{2}{|c|}{ IV probit } \\
\hline & $\begin{array}{c}1 \\
\text { Coef. }\end{array}$ & $\begin{array}{c}2 \\
\text { Marginal } \\
\text { effect }\end{array}$ & & $\begin{array}{c}4 \\
\text { Coef. }\end{array}$ & $\begin{array}{c}5 \\
\text { Marginal } \\
\text { effect }\end{array}$ \\
\hline Customer CAR (generic) & $\begin{array}{l}16.106^{* *} \\
(2.39)\end{array}$ & 2.046 & $\begin{array}{c}-86.049 \\
(-0.56)\end{array}$ & $\begin{array}{r}5.879 \\
(1.43)\end{array}$ & 0.741 \\
\hline Residual, Customer CAR (generic) & & & $\begin{array}{r}103.415 \\
(0.68)\end{array}$ & & \\
\hline Customer CAR (local) & $\begin{array}{l}-11.728^{* * *} \\
(-2.80)\end{array}$ & 490 & $\begin{array}{c}-330.889^{* *} \\
(-2.11)\end{array}$ & & \\
\hline Residual, Customer CAR (local) & & & $\begin{array}{l}319.796^{* *} \\
(2.05)\end{array}$ & & \\
\hline Fitted value, Customer CAR (local) & & & & $\begin{array}{l}-29.911 \\
(-1.21)\end{array}$ & -3.768 \\
\hline Rival CAR (local) & $\begin{array}{l}-8.349^{* * *} \\
(-2.55)\end{array}$ & -1.061 & $\begin{array}{c}53.955 \\
(0.57)\end{array}$ & $\begin{array}{l}-9.110^{* *} \\
(-2.42)\end{array}$ & -1.148 \\
\hline Residual, Rival CAR (local) & & & $\begin{array}{l}-60.903 \\
(-0.65)\end{array}$ & & \\
\hline Rival CAR (distant) & $(1.17)$ & 0.882 & $\begin{array}{c}1236.663^{*} \\
(1.81)\end{array}$ & $\begin{array}{r}5.282 \\
(0.90)\end{array}$ & 0.665 \\
\hline Residual, Rival CAR (distant) & & & $\begin{array}{c}-1229.049^{*} \\
(-1.80)\end{array}$ & & \\
\hline Combined CAR & $\begin{array}{r}-1.967 \\
(-0.90)\end{array}$ & -0.250 & $\begin{array}{l}-25.299^{* * *} \\
(-3.22)\end{array}$ & & \\
\hline Residual, Combined CAR & & & $\begin{array}{l}22.950^{* * *} \\
(2.65)\end{array}$ & & \\
\hline Fitted value, Combined CAR & & & & $\begin{array}{l}-10.565^{*} \\
(-1.65)\end{array}$ & -1.331 \\
\hline Import ratio & $\begin{array}{l}-4.752^{* * *} \\
(-4.64)\end{array}$ & -0.604 & $\begin{array}{r}2.428 \\
(0.40)\end{array}$ & $\begin{array}{l}-6.234^{* * *} \\
(-4.99)\end{array}$ & -0.785 \\
\hline Census hurdle dummy & $\begin{array}{l}0.894^{* *} \\
(2.14)\end{array}$ & 0.161 & $\begin{array}{r}-6.745 \\
(-1.56)\end{array}$ & $\begin{array}{r}0.830 \\
(1.56)\end{array}$ & 0.145 \\
\hline Industry growth & $\begin{array}{l}-0.197 \\
(-0.89)\end{array}$ & -0.025 & $\begin{array}{l}-2.171^{*} \\
(-1.76)\end{array}$ & $\begin{array}{l}-0.212 \\
(-1.01)\end{array}$ & -0.027 \\
\hline Relative deal size & $\begin{array}{l}0.615^{* * *} \\
(2.64)\end{array}$ & 0.078 & $\begin{array}{l}-2.353 \\
(-1.39)\end{array}$ & $\begin{array}{l}0.728^{* *} \\
(2.34)\end{array}$ & 0.092 \\
\hline Census bidder market share & $\begin{array}{l}-0.390 \\
(-0.93)\end{array}$ & -0.050 & $\begin{array}{l}-2.608^{* *} \\
(-2.02)\end{array}$ & $\begin{array}{l}-2.253 \\
(-0.67)\end{array}$ & -0.032 \\
\hline Ln Bidder market cap & $\begin{array}{l}0.263^{* * *} \\
(6.55)\end{array}$ & 0.033 & $\begin{array}{l}0.554^{* *} \\
(2.29)\end{array}$ & $\begin{array}{l}0.212^{* * * *} \\
(4.72)\end{array}$ & 0.027 \\
\hline Year effects & $\mathrm{Y}$ & & $\mathrm{Y}$ & $\mathrm{Y}$ & \\
\hline Pseudo $R^{2}$ & 0.30 & & 0.35 & 0.30 & \\
\hline Observations & 282 & & 282 & 282 & \\
\hline
\end{tabular}


Table 6 (continued)

Panel B: The impact of local rival and distant rival's wealth effects on antitrust case selection (controlling for reliant customer CAR)

\begin{tabular}{|c|c|c|c|c|c|}
\hline \multirow{3}{*}{ Independent Variable } & \multicolumn{5}{|c|}{ Dependent variable: Antitrust challenge } \\
\hline & \multicolumn{2}{|c|}{ Probit } & \multirow{2}{*}{$\begin{array}{c}\text { Endog. test } \\
3 \\
\text { Coef. }\end{array}$} & \multicolumn{2}{|c|}{ IV probit } \\
\hline & $\begin{array}{c}1 \\
\text { Coef. }\end{array}$ & $\begin{array}{c}2 \\
\text { Marginal } \\
\text { effect }\end{array}$ & & $\begin{array}{c}4 \\
\text { Coef. }\end{array}$ & $\begin{array}{c}5 \\
\text { Marginal } \\
\text { effect }\end{array}$ \\
\hline Customer CAR (generic) & $\begin{array}{r}0.090 \\
(0.01)\end{array}$ & 0.013 & $\begin{array}{r}189.615 \\
(1.00)\end{array}$ & $\begin{array}{l}3.356 \\
(0.47)\end{array}$ & 0.460 \\
\hline Residual, Customer CAR (generic) & & & $\begin{array}{r}-191.246 \\
(-1.02)\end{array}$ & & \\
\hline Customer CAR (reliant) & $\begin{array}{l}4.098 \\
(1.15)\end{array}$ & 0.579 & $\begin{array}{r}-130.013 \\
(-2.28)\end{array}$ & & \\
\hline Residual, Customer CAR (reliant) & & & $\begin{array}{r}135.179^{* *} \\
(2.41)\end{array}$ & & \\
\hline Fitted value, Customer CAR (reliant) & & & & $\begin{array}{l}-9.325 \\
(-0.66)\end{array}$ & -1.277 \\
\hline Rival CAR (local) & $\begin{array}{l}-13.230^{* * *} \\
(-3.16)\end{array}$ & -1.871 & -26.844 & $\begin{array}{l}-12.081^{* * *} \\
(-3.08)\end{array}$ & -1.655 \\
\hline Residual, Rival CAR (local) & & & 12.738 & & \\
\hline Rival CAR (distant) & $\begin{array}{l}14.205^{* * *} \\
(2.60)\end{array}$ & & $\begin{array}{c}642.152 \\
(1.16)\end{array}$ & $\begin{array}{l}14.939^{* *} \\
(2.40)\end{array}$ & 2.046 \\
\hline Residual, Rival CAR (distant) & & & $\begin{array}{r}-619.989 \\
(-1.12)\end{array}$ & & \\
\hline Combined CAR & $\begin{array}{l}-0.564 \\
(-0.18)\end{array}$ & 0.080 & $\begin{array}{l}-36.068^{* * * *} \\
(-3.80)\end{array}$ & & \\
\hline Residual, Combined CAR & & & $\begin{array}{l}34.857^{* * * *} \\
(3.38)\end{array}$ & & \\
\hline Fitted value, Combined CAR & & & & $\begin{array}{l}-19.989^{* *} \\
(-1.98)\end{array}$ & -2.738 \\
\hline Import ratio & & -0.572 & $\begin{array}{l}-4.088 \\
(-0.70)\end{array}$ & $\begin{array}{l}-7.065^{* * *} \\
(-2.86)\end{array}$ & -0.968 \\
\hline Census hurdle dummy & $\begin{array}{l}0.261 \\
(0.54)\end{array}$ & 0.041 & $\begin{array}{r}0.227 \\
(0.10)\end{array}$ & $\begin{array}{c}0.496 \\
(0.89)\end{array}$ & 0.081 \\
\hline Industry growth & $\begin{array}{l}-0.549 \\
(-1.55)\end{array}$ & -0.078 & $\begin{array}{l}-2.024^{*} \\
(-1.91)\end{array}$ & $\begin{array}{l}-0.445^{*} \\
(-1.74)\end{array}$ & -0.061 \\
\hline Relative deal size & $\begin{array}{l}0.535^{* *} \\
(2.23)\end{array}$ & 0.076 & $\begin{array}{c}0.394 \\
(0.37)\end{array}$ & $\begin{array}{l}0.894^{* *} \\
(2.20)\end{array}$ & 0.122 \\
\hline Census bidder market share & $\begin{array}{l}-0.247 \\
(-0.96)\end{array}$ & -0.035 & $\begin{array}{l}-2.208^{*} \\
(-1.86)\end{array}$ & $\begin{array}{l}0.007 \\
(0.02)\end{array}$ & 0.001 \\
\hline Ln Bidder market cap & $\begin{array}{l}0.272^{* * *} \\
(5.22)\end{array}$ & 0.038 & $\begin{array}{c}0.093 \\
(0.75)\end{array}$ & $\begin{array}{l}0.159^{* *} \\
(2.26)\end{array}$ & 0.022 \\
\hline Year effects & Y & & Y & Y & \\
\hline $\begin{array}{l}\text { Pseudo } \mathrm{R}^{2} \\
\text { Observations }\end{array}$ & $\begin{array}{l}0.28 \\
182 \\
\end{array}$ & & $\begin{array}{c}0.35 \\
182 \\
\end{array}$ & $\begin{array}{r}0.30 \\
182 \\
\end{array}$ & \\
\hline
\end{tabular}


Table 7

\section{The impact of specialized rival and less specialized rival wealth effects on antitrust case selection (robustness test)}

The table reports robustness test results for the impacts of less specialized rivals and specialized rivals wealth effects on antitrust case selection. Panel A controls for local customer wealth effect, while panel B controls for reliant customer wealth effect. In panels $\mathrm{A}$ and $\mathrm{B}$, columns 1 and 2 report coefficients and marginal effects of uninstrumented probit regressions. Columns 3 reports Rivers and Vuong (1988) endogeneity tests of measures of the wealth effect. Columns 4 and 5 report coefficients and marginal effects of two-step instrumental variable probit regressions. Residuals and fitted values are from the first-step OLS regressions in Appendix 5. Appendix 3 defines all variables. All variables are winsorized at the $1^{\text {st }}$ and $99^{\text {th }}$ percentiles. $z$-statistics are in parentheses. ${ }^{*}, * *$, and ${ }^{* * * *}$ denote significance of probit and endogeneity test coefficients at $10 \%, 5 \%$, and $1 \%$.

Panel A: The impact of specialized rival and less specialized rival's wealth effects on antitrust case selection (controlling for local customer CAR)

\begin{tabular}{|c|c|c|c|c|c|}
\hline \multirow{3}{*}{ Independent Variable } & \multicolumn{5}{|c|}{ Dependent variable: Antitrust challenge } \\
\hline & \multicolumn{2}{|c|}{ Probit } & Endog. test & \multicolumn{2}{|c|}{ IV probit } \\
\hline & $\begin{array}{c}1 \\
\text { Coef. }\end{array}$ & $\begin{array}{c}2 \\
\text { Marginal } \\
\text { effect }\end{array}$ & $\begin{array}{c}3 \\
\text { Coef. }\end{array}$ & $\begin{array}{c}4 \\
\text { Coef. }\end{array}$ & $\begin{array}{c}5 \\
\text { Marginal } \\
\text { effect }\end{array}$ \\
\hline Customer CAR (generic) & $\begin{array}{l}15.180^{* * *} \\
(2.13)\end{array}$ & 2.046 & $\begin{array}{r}-328.367 \\
(-1.15)\end{array}$ & $\begin{array}{c}6.250 \\
(1.35)\end{array}$ & 0.780 \\
\hline Residual, Customer CAR (generic) & & & $\begin{array}{r}346.025 \\
(1.22)\end{array}$ & & \\
\hline Customer CAR (local) & $\begin{array}{l}-11.315^{* *} \\
(-2.40)\end{array}$ & 490 & $\begin{array}{c}-508.930^{* *} \\
(-2.43)\end{array}$ & & \\
\hline Residual, Customer CAR (local) & & & $\begin{array}{l}496.923^{* *} \\
(2.37)\end{array}$ & & \\
\hline Fitted value, Customer CAR (local) & & & & $\begin{array}{c}-24.705 \\
(-1.04)\end{array}$ & -3.085 \\
\hline Rival CAR (less specialized) & $\begin{array}{l}-10.384^{*} \\
(-2.52)\end{array}$ & -1.061 & $\begin{array}{c}1311.240^{*} \\
(1.86)\end{array}$ & $\begin{array}{l}-12.402^{* * *} \\
(-2.91)\end{array}$ & -1.549 \\
\hline Residual, Rival CAR (less specialized) & & & $\begin{array}{c}-1320.172^{*} \\
(-1.88)\end{array}$ & & \\
\hline Rival CAR (specialized) & & 0.882 & $\begin{array}{c}307.022^{*} \\
(1.78)\end{array}$ & $\begin{array}{r}5.584 \\
(1.54)\end{array}$ & 0.697 \\
\hline Residual, Rival CAR (specialize & & & $\begin{array}{c}-301.351^{*} \\
(-1.75)\end{array}$ & & \\
\hline Combined CAR & $\begin{array}{l}-1.175 \\
(-0.52)\end{array}$ & -0.250 & $\begin{array}{l}-25.337^{* * *} \\
(-3.16)\end{array}$ & & \\
\hline Residual, Combined CAR & & & $\begin{array}{l}24.147^{* * * *} \\
(2.88)\end{array}$ & & \\
\hline Fitted value, Combined CAR & & & & $\begin{array}{l}-11.733^{*} \\
(-1.68)\end{array}$ & -1.465 \\
\hline Import ratio & $\begin{array}{l}-4.341^{* * *} \\
(-4.01)\end{array}$ & -0.604 & $\begin{array}{c}0.848 \\
(0.17)\end{array}$ & $\begin{array}{l}-6.151^{* * *} \\
(-4.25)\end{array}$ & -0.768 \\
\hline Census hurdle dummy & $\begin{array}{l}1.119^{* * * *} \\
(3.06)\end{array}$ & 0.161 & $\begin{array}{l}-4.182 \\
(-1.42)\end{array}$ & $\begin{array}{l}1.180^{* *} \\
(2.45)\end{array}$ & 0.223 \\
\hline Industry growth & $\begin{array}{l}-0.188 \\
(-0.94)\end{array}$ & -0.025 & $\begin{array}{l}-1.492^{*} \\
(-1.65)\end{array}$ & $\begin{array}{l}-0.199 \\
(-1.12)\end{array}$ & -0.025 \\
\hline Relative deal size & $\begin{array}{l}0.548^{* * *} \\
(2.59)\end{array}$ & 0.078 & $\begin{array}{l}-2.434 \\
(-1.61)\end{array}$ & $\begin{array}{l}0.708^{* *} \\
(2.46)\end{array}$ & 0.088 \\
\hline Census bidder market share & $\begin{array}{l}-0.375 \\
(-0.96)\end{array}$ & -0.050 & $\begin{array}{l}1.874 \\
(1.19)\end{array}$ & $\begin{array}{l}-0.244 \\
(-0.68)\end{array}$ & -0.030 \\
\hline Ln Bidder market cap & $\begin{array}{l}0.283^{* * *} \\
(6.91)\end{array}$ & 0.033 & $\begin{array}{r}0.087 \\
(0.26)\end{array}$ & $\begin{array}{l}0.232^{* * *} \\
(4.41)\end{array}$ & 0.029 \\
\hline Year effects & Y & & $\mathrm{Y}$ & Y & \\
\hline Pseudo $\mathrm{R}^{2}$ & 0.32 & & 0.38 & 0.33 & \\
\hline Observations & 290 & & 290 & 290 & \\
\hline
\end{tabular}


Table 7 (continued)

Panel B: The impact of specialized rival and less specialized rival's wealth effects on antitrust case selection (controlling for reliant customer CAR)

\begin{tabular}{|c|c|c|c|c|c|}
\hline \multirow{3}{*}{ Independent Variable } & \multicolumn{5}{|c|}{ Dependent variable: Antitrust challenge } \\
\hline & \multicolumn{2}{|c|}{ Probit } & \multirow{2}{*}{$\begin{array}{c}\text { Endog. test } \\
3 \\
\text { Coef. }\end{array}$} & \multicolumn{2}{|c|}{ IV probit } \\
\hline & $\begin{array}{c}1 \\
\text { Coef. }\end{array}$ & $\begin{array}{c}2 \\
\text { Marginal } \\
\text { effect }\end{array}$ & & $\begin{array}{c}4 \\
\text { Coef. }\end{array}$ & $\begin{array}{c}5 \\
\text { Marginal } \\
\text { effect }\end{array}$ \\
\hline Customer CAR (generic) & $\begin{array}{c}3.119 \\
(0.44)\end{array}$ & 0.447 & $\begin{array}{c}232.229 \\
(1.00)\end{array}$ & $\begin{array}{l}1.918 \\
(0.24)\end{array}$ & 0.266 \\
\hline Residual, Customer CAR (generic) & & & $\begin{array}{c}-231.164 \\
(-1.01)\end{array}$ & & \\
\hline Customer CAR (reliant) & $\begin{array}{r}0.617 \\
(0.20)\end{array}$ & 0.088 & $\begin{array}{l}-58.207 \\
(-1.01)\end{array}$ & $\begin{array}{c}0.761 \\
(0.28)\end{array}$ & 0.105 \\
\hline Residual, Customer CAR (reliant) & & & $\begin{array}{c}60.365 \\
(1.04)\end{array}$ & & \\
\hline Rival CAR (less specialized) & $\begin{array}{l}-0.263 \\
(-0.04)\end{array}$ & -0.038 & $\begin{array}{l}-41.029 \\
(-0.09)\end{array}$ & $\begin{array}{l}-0.398 \\
(-0.06)\end{array}$ & -0.055 \\
\hline Residual, Rival CAR (less specialized) & & & 43.079 & & \\
\hline Rival CAR (specialized) & $\begin{array}{l}-0.956 \\
(-0.24)\end{array}$ & -0.137 & $\begin{array}{l}60.679 \\
(0.53)\end{array}$ & $\begin{array}{l}0.116 \\
(0.03)\end{array}$ & 0.016 \\
\hline Residual, Rival CAR (specialized) & & & $\begin{array}{l}-61.048 \\
(-0.55)\end{array}$ & & \\
\hline Combined CAR & $\begin{array}{l}-0.805 \\
(-0.32)\end{array}$ & 0.115 & $\begin{array}{l}-27.105^{* * *} \\
(-3.64)\end{array}$ & & \\
\hline Residual, Combined CAR & & & $\begin{array}{l}26.350^{* * * *} \\
(3.24)\end{array}$ & & \\
\hline Fitted value, Combined CAR & & & & $\begin{array}{l}-21.593^{*} \\
(-1.95)\end{array}$ & -2.991 \\
\hline Import ratio & $\begin{array}{l}-4.282^{* * * *} \\
(-2.99)\end{array}$ & -0.613 & $\begin{array}{l}-7.981^{*} \\
(-1.94)\end{array}$ & $\begin{array}{l}-7.913^{* * *} \\
(-2.76)\end{array}$ & -1.096 \\
\hline Census hurdle dummy & $\begin{array}{l}0.889^{* *} \\
(2.38)\end{array}$ & 0.177 & $\begin{array}{l}2.774^{* * *} \\
(2.65)\end{array}$ & $\begin{array}{l}0.978^{* *} \\
(2.38)\end{array}$ & 0.190 \\
\hline Industry growth & $\begin{array}{l}-0.288 \\
(-1.17)\end{array}$ & -0.025 & $\begin{array}{l}-0.395 \\
(-0.50)\end{array}$ & $\begin{array}{l}-0.210 \\
(-1.30)\end{array}$ & -0.029 \\
\hline Relative deal size & $\begin{array}{l}0.453^{* * * *} \\
(2.60)\end{array}$ & 0.065 & $\begin{array}{r}1.242^{*} \\
(-1.72)\end{array}$ & $\begin{array}{l}0.800^{* * *} \\
(2.51)\end{array}$ & 0.111 \\
\hline Census bidder market share & $\begin{array}{l}-0.152 \\
(-0.57)\end{array}$ & -0.022 & $\begin{array}{l}-0.786 \\
(-0.70)\end{array}$ & $\begin{array}{c}0.091 \\
(0.28)\end{array}$ & 0.013 \\
\hline Ln Bidder market cap & $\begin{array}{l}0.225^{* * * *} \\
(3.88)\end{array}$ & 0.032 & $\begin{array}{c}0.116 \\
(0.33)\end{array}$ & $\begin{array}{r}0.129 \\
(1.62)\end{array}$ & 0.018 \\
\hline Year effects & $\mathrm{Y}$ & & $\mathrm{Y}$ & $\mathrm{Y}$ & \\
\hline $\begin{array}{l}\text { Pseudo } \mathrm{R}^{2} \\
\text { Observations }\end{array}$ & $\begin{array}{l}0.27 \\
197 \\
\end{array}$ & & $\begin{array}{l}0.33 \\
197 \\
\end{array}$ & $\begin{array}{l}0.30 \\
197 \\
\end{array}$ & \\
\hline
\end{tabular}




\section{Appendix 1: Summary of challenged deal details in the manufacturing sector}

Challenged cases in the study, listing bidder name, target name, their overlapping operating segment, the antitrust agency that files the challenge and the complaint issuance documented in the FTC and DOJ's joint "Annual Report to Congress Pursuant to Subsection (j) of Section 7A of the Clayton Act Hart-ScottRodino Antitrust Improvements Act of 1976".

\begin{tabular}{|c|c|c|c|c|c|c|c|}
\hline No. & $\begin{array}{l}\text { Announcement } \\
\text { Year }\end{array}$ & Bidder Name & Target Name & SIC & $\begin{array}{l}\text { Fama-French } \\
\text { Industries }\end{array}$ & Agency & Record from Agency Report \\
\hline 1 & 1982 & ConAgra Inc & Peavey Co & 2041 & FOOD & FTC & $\begin{array}{l}\text { FTC Consent agreement accepted July 19, } 1982 . \\
\text { Documented in } 1982 \text { annual report. }\end{array}$ \\
\hline 2 & 1982 & Gulf Oil Corp & Cities Service Co & 2911 & OIL & FTC & Civil Action No. 82-2131 (D.D.C. filed July 29, 1982). \\
\hline 3 & 1983 & LTV Corp & $\begin{array}{l}\text { Republic Steel } \\
\text { Corp(LTV Corp) }\end{array}$ & 3312 & STEEL & DOJ & Cv. No. 85-0884 (D.D.C. filed March 21, 1984). \\
\hline 4 & 1984 & Texaco Inc & Getty Oil Co & 2911 & OIL & & FTC Consent agreement accepted July 10, 1984. \\
\hline 5 & 1994 & IVAX Corp & Zenith Laboratories Inc & 2834 & DRUGS & $\mathrm{C}$ & Docket No. C-3565, issued March 27, 1995. \\
\hline 6 & 1994 & Boston Scientific Corp & $\begin{array}{l}\text { SciMed Life Systems } \\
\text { Inc }\end{array}$ & 3841 & MEDEQ & FTC & Docket No. C-3573, issued April 28, 1995. \\
\hline 7 & 1995 & Interstate Bakeries Corp & $\begin{array}{l}\text { Ralston-Continental } \\
\text { Baking Company }\end{array}$ & 2051 & FOOD & DOJ & Cv. No. 95C4194 (N.D. Ill. filed July 20, 1995). \\
\hline 8 & 1995 & Kimberly-Clark Corp & Scott Paper Co & 2621 & PAPER & FTC & $\begin{array}{l}\text { Cv. No. 3:95CV3055-P (N.D. Tex. Filed December 12, } \\
\text { 1995). }\end{array}$ \\
\hline 9 & 1996 & Lockheed Martin Corp & Loral Corp & 3812 & CHIPS & FTC & Docket No. C-3685, issued September 19, 1996. \\
\hline 10 & 1997 & Lockheed Martin Corp & $\begin{array}{l}\text { Northrop Grumman } \\
\text { Corp }\end{array}$ & 3812 & CHIPS & DOJ & $\begin{array}{l}\text { DOJ complaint issued March 23, 1998. Documented in } \\
1998 \text { annual report. }\end{array}$ \\
\hline 11 & 1998 & Suiza Foods Corp & Broughton Foods Co & 2026 & FOOD & DOJ & 99-CV-130, DOJ complaint issued March 18, 1999. \\
\hline 12 & 1998 & Medtronic Inc & Physio-Control & 3845 & MEDEQ & FTC & Docket No. C-3879, issued June 3, 1999. \\
\hline 13 & 1999 & Rhone-Poulenc $S$ & Hoechst AG & 2834 & DRUGS & FTC & Docket No. C-3919, issued January 28, 2000. \\
\hline 14 & 1999 & Pfizer Inc & Warner-Lambert Co & 2834 & DRUGS & FTC & Docket No. C-3957, issued July 28, 2000. \\
\hline 15 & 1999 & Dow Chemical Co & Union Carbide Corp & 2869 & CHEM & FTC & Docket No. C-3999, issued March 16, 2001. \\
\hline 16 & 1999 & Rohm \& Haas Co & $\begin{array}{l}\text { Morton International } \\
\text { Inc }\end{array}$ & 2899 & CHEM & FTC & Docket No. C-3883, issued July 13, 1999. \\
\hline 17 & 1999 & General Dynamics Corp & $\begin{array}{l}\text { Newport News } \\
\text { Shipbuilding Inc }\end{array}$ & 3731 & SHIPS & DOJ & Civil No: 1:01CV02200, filed October 23, 2001. \\
\hline 18 & 1999 & Litton Industries Inc & $\begin{array}{l}\text { Newport News } \\
\text { Shipbuilding Inc }\end{array}$ & 3731 & SHIPS & DOJ & $\begin{array}{l}\text { DOJ complaint issued July 9, 1999. Documented in } 1999 \\
\text { annual report. }\end{array}$ \\
\hline
\end{tabular}




\begin{tabular}{|c|c|c|c|c|c|c|c|}
\hline & \multicolumn{7}{|c|}{ Appendix 1 (continued) } \\
\hline No. & $\begin{array}{c}\text { Announcement } \\
\text { Year }\end{array}$ & Bidder Name & Target Name & SIC & $\begin{array}{l}\text { Fama-French } \\
\text { Industries }\end{array}$ & Agency & Record from Agency Report \\
\hline 19 & 2000 & Smithfield Foods Inc & IBP Inc & 2011 & FOOD & DOJ & $\begin{array}{l}\text { Civil Action No. 1:03CV00434 (HHK), filed } 28 \\
\text { February, } 2003 .\end{array}$ \\
\hline 20 & 2000 & Valspar Corp & Lilly Industries Inc & 2851 & CHEM & FTC & Docket No. C-3995, issued January 26, 2001. \\
\hline 21 & 2000 & JDS Uniphase Corp & $\begin{array}{l}\text { E-Tek Dynamics } \\
\text { Inc(Summit Partners LP) }\end{array}$ & 3674 & CHIPS & DOJ & $\begin{array}{l}\text { C.V. No. C } 002227 \text { (THE) (N.D. Cal. Filed June 22, } \\
\text { 2000). }\end{array}$ \\
\hline 22 & 2001 & Valero Energy Corp & Huntway Refining Co & 2911 & OIL & FTC & Docket No. C-4031, issued February 19, 2002. \\
\hline 23 & 2001 & General Dynamics Corp & $\begin{array}{l}\text { Newport News } \\
\text { Shipbuilding Inc }\end{array}$ & 3731 & SHIPS & DOJ & No. 1:01CV02200 (D.D.C. Oct.23, 2001). \\
\hline 24 & 2002 & Pfizer Inc & Pharmacia Corp & 2834 & DRUGS & & Docket No. C- 4075, issued May 27, 2003. \\
\hline 25 & 2002 & $\begin{array}{l}\text { Northrop Grumman } \\
\text { Corp }\end{array}$ & TRW Inc & 3728 & $\Delta F$ & DOJ & No. 1:02CV02432 (D.D.C. filed Dec.11, 2002). \\
\hline 26 & 2003 & Cephalon Inc & CIMA Labs Inc & 2834 & DRUGS & FTC & Docket No. C-4121, issued September 20, 2004. \\
\hline 27 & 2004 & Genzyme Corp & ILEX Oncology Inc & 2836 & DRUGS & FTC & Docket No. C-4128, issued December 20, 2004. \\
\hline 28 & 2005 & $\begin{array}{l}\text { Teva Pharmaceutical } \\
\text { Industries Ltd }\end{array}$ & IVAX Corp & 2834 & DRUGS & FTC & Docket No. C-4155, issued January 20, 2006. \\
\hline 29 & 2005 & Procter \& Gamble Co & Gillette Co & 2844 & HSHLD & FTC & Docket No. C-4151, issued September 29, 2005. \\
\hline 30 & 2005 & Boston Scientific Corp & Guidant Corp & 3841 & MEDEQ & FTC & Docket No. C-4164, issued July 21, 2006. \\
\hline 31 & 2006 & $\begin{array}{l}\text { Watson } \\
\text { Pharmaceuticals Inc }\end{array}$ & Andrx Corp & 2834 & DRUGS & FTC & Docket No. C-4172, issued October 31, 2006. \\
\hline 32 & 2007 & CommScope Inc & Andrew Corp & 3357 & STEEL & DOJ & No. 1:07-CV-02200 (D.D.C. filed Dec.6, 2007). \\
\hline 33 & 2009 & Pfizer Inc & Wyeth & 2834 & DRUGS & FTC & $\begin{array}{l}\text { Docket No. C-4267, proposed order issued Oct.14, } \\
2009 .\end{array}$ \\
\hline 34 & 2009 & Merck \& Co Inc & Schering-Plough Corp & 2834 & DRUGS & FTC & $\begin{array}{l}\text { Docket No. C-4268, proposed order issued Oct.29, } \\
2009 .\end{array}$ \\
\hline 35 & 2009 & Agrium Inc & $\begin{array}{l}\text { CF Industries Holdings } \\
\text { Inc }\end{array}$ & 2873 & CHEM & FTC & $\begin{array}{l}\text { Docket No. C-4277, proposed order issued Dec. } 23 \text {, } \\
2009 .\end{array}$ \\
\hline
\end{tabular}




\section{Appendix 2: Key variable construction process}

\section{Corporate customer identification}

Following Shahrur (2005), we employ the Use table from the BEA Benchmark IO accounts to identify the corporate customers of each horizontal merger. We include only single-segment customer firms to preserve test power by excluding customers that have segments unrelated to the merging industry. This requirement excludes customers firms that also have segments in the merging industry. Song and Walkling (2000) caution that merger announcements release information about the merging industry and therefore affect firms that have segments in the merging industry. The single-segment requirement pre-empts this confounding effect.

Similar to Shahrur (2005), we form generic, local, and reliant customer portfolios for our sample deals. We construct a region-based local customer portfolio that includes all regional customers with an industry CIC over $1 \%$. For robustness, we replace region-based by a state-based geographic classification, i.e., defining a customer as local if its headquarters is in either the target or bidder headquarter state, and find results that are qualitatively similar. ${ }^{20}$

The SDC, Compustat and the Use tables use different industry classifications, i.e., the SDC and Compustat use four-digit SIC codes, while the Use table use six-digit IO codes. For IO-SIC matching, we adopt a series of approaches. For the 1982, 1987, and 1992 Use tables, we follow Shahrur (2005) and use the conversion tables of Fan and Lang (2000) to directly convert IO to SIC codes. We include an industry only if we can match its SIC code to a unique IO code. For the 1997 and 2002 Use tables, since there is no direct IO-SIC mapping available, we adopt the conversion strategy of Bhattacharyya and Nain (2011). First, we use the BEA IO-North American Industrial Classification System (NAICS) conversion tables to convert IO codes to NAICS codes. ${ }^{21}$ Then we use correspondence tables from the U.S. Census Bureau to convert NAICS to SIC codes. ${ }^{22}$ Finally, we match all 1982, 1987, 1992, 1997, and 2002 Use tables data to our merger sample using SDC SIC codes.

Given that product market relations evolve over time, we use the 1982, 1987, 1992, 1997 and 2002 Use tables for proposed deals during 1980-1986, 1987-1991, 1992-1996, 1997-2001, and 2002-2009 respectively. We find similar results repeating our analysis using the 1982, 1987, 1992, 1997 and 2002 Use tables for deals occurring during 1980-1984, 1985-1989, 1990-1994, 1995-1999, and 2000-2009 respectively. Our reported results use the first matching set of Use tables since this involves minimum hindsight bias.

\footnotetext{
${ }^{20}$ The following states are in each of the regions. Northeast: Connecticut, Delaware, District of Colombia, Massachusetts, Maine, Maryland, New Hampshire, New Jersey, New York, Pennsylvania, Rhode Island, and Vermont. Southeast: Alabama, Florida, Georgia, Kentucky, Mississippi, North Carolina, South Carolina, Tennessee, and Virginia. Southwest: Arizona, Arkansas, Louisiana, New Mexico, Oklahoma, and Texas. Mideast: Illinois, Indiana, Michigan, Ohio, West Virginia, and Wisconsin. Midwest: Iowa, Kansas, Minnesota, Missouri, Nebraska, North Dakota, and South Dakota. West: Alaska, California, Colorado, Hawaii, Idaho, Montana, Nevada, Oregon, Utah, Washington, and Wyoming.

${ }^{21}$ The IO-NAICS concordance for 1997 is available in Appendix A of the "Benchmark Input-Output Accounts of the United States, 1997", available at http://www.bea.gov/scb/pdf/2002/12December/1202I-OAccounts2.pdf. The IO-NAICS concordance for 2002 is available in Appendix A of the "U.S. Benchmark Input-Output Accounts, 2002", available at http://www.bea.gov/scb/pdf/2007/10\%20October/1007_benchmark_io.pdf.

${ }^{22}$ The 1997 and 2002 NAICS-SIC concordance tables are available at http://www.census.gov/eos/www/naics/concordances/concordances.html. In mapping IO to SIC for the 1997 and 2002 Use tables, for robustness, we further require that an IO code corresponds to a unique NAICS code and an NAICS code corresponds to a unique SIC code in order to retain a cleaner matching pattern, for the 1997 and 2002 Use tables. We find that this stricter restriction does not qualitatively change our conclusions. However, this restriction substantially reduces the number of identified 1997 and 2002 upstream-downstream industry pairs. Therefore, we do not apply this restriction.
} 


\section{Industry rival identification}

Following Fee and Thomas (2004), we form generic, local, distant, less specialized, and specialized rival portfolios for our sample deals. In particular, we construct a region-based local rival portfolio that includes all rivals if their headquarters are in the same region as either the bidder's or the target's. For robustness, we also employ the state-based classification and obtain similar results. ${ }^{23}$

Unlike customer portfolios, rival portfolios include single- and multi-segment firms. Although this adds noise to the rival wealth effects, it preserves the influence construct because multi-segment firms are often large rivals who play a significant influencing role. We exercise caution by excluding rivals who at the same time have segments in the customer industry.

\section{Measuring wealth effects at the merger announcement}

To measure the wealth effects of related firms, we use an event study methodology and calculate abnormal returns using the market model,

$$
A R_{i t}=R_{i t}-\widehat{\alpha}_{\imath}-\widehat{\beta}_{\imath} R_{m t},
$$

where $R_{m t}$ is the CRSP equally-weighted market index return on day $t, R_{i t}$ is firm $i$ 's return on day $t$ and $\widehat{\alpha}_{l}$ and $\widehat{\beta}_{l}$ are coefficients from the market model estimated over 250 trading days starting from day -300 before the announcement date (day 0). We require a firm to have at least 100 daily returns available during the estimation period. Our analysis uses the cumulative abnormal return from two days before to two days after the merger announcement, i.e., $\operatorname{CAR}(-2,2)$.

To calculate the combined wealth effect of merging firms (Combined $C A R$ ), we value-weight bidder and target $C A R(-2,2)$ by the relative market capitalizations of the bidder and target at the fiscal year end before the merger, excluding the value of any pre-merger holdings in the target by the bidder (e.g., Bradley, Desai, and Kim, 1988; Fee and Thomas, 2004).

\section{Import ratio as a measure of the level of foreign competition}

Following Mitchell and Mulherin (1996) and Shahrur (2005), we measure the intensity of foreign competition using the Import Ratio calculated as the merging industry's total imports divided by its total domestic supply. Raw data for constructing the Import Ratio are from the 1982, 1987, 1992, 1997, and 2002 BEA Use tables. Domestic supply is commodity output minus imports, exports, change in private inventories and sales of scrap and used goods (Streitwieser, 2010). We also follow Giroud and Mueller (2010) and Valva (2012) to use an alternative metric, industry penetration (calculated as total value of imports divided by total value of imports plus domestic production) and obtain similar results.

\footnotetext{
${ }^{23}$ There are 26 state-based local rivals (median of 9) and 80 distant rivals (median of 43) for an average deal. If we include only single-segment rivals, there are 12 state-based local rivals (median of 5) and 32 distant rivals (median of 20) for an average deal. This state-based local rival portfolio size is fairly close to Shahrur's (2005) mean (median) state-based local rival portfolio size of 13 (4).
} 


\section{Market concentration}

Sales-based HHI is a widely adopted measure of market concentration. To calculate it, previous literature uses Compustat data or, more recently, U.S. Census Bureau census data (Bhattacharyya and Nain, 2011; Ahern, 2012). Ali, Klasa, and Yeung (2009) find that HHI based on Compustat data has a correlation of only 13\% with an HHI based on census data. This is because Compustat covers only public firms whereas the U.S. Census Bureau census covers public and private firms. We measure industry concentration using the Census Herfindahl Index for each four-digit SIC industry, i.e., the census concentration estimate reported by the Census Bureau divided by $10000 .{ }^{24}$ We also calculate the change in concentration (i.e., $\Delta$ Census Herfindahl Index) as $2 \times$ target market share $\times$ bidder market share measured in the year before the merger announcement. Bidder and target market shares are Compustat segment sales divided by census-based industry sales.

To test the market concentration hurdle hypothesis, we define a Census Hurdle Dummy according to the criteria outlined in the 1992 DOJ/FTC Horizontal Merger Guidelines. In particular, Census Hurdle Dummy equals one if a deal satisfies one of the following two thresholds: a) Census Herfindahl Index exceeds 0.18 and $\Delta$ Census Herfindahl Index is no less than 0.005, or b) Census Herfindahl Index is between 0.1 and 0.18 and $\Delta$ Census Herfindahl Index is no less than 0.01, otherwise zero.

In the 1982, 1987, and 1992 censuses, the U.S. Census Bureau conducted concentration data surveys only for the manufacturing sector. From 1997 onwards, the census data cover the business service sector. For consistency, we examine only manufacturing sector deals.

\footnotetext{
${ }^{24}$ Since the census is conducted every five years, it is impossible to derive an accurate concentration measure for each year. We use 1982, 1987, and 1992 SIC-based census concentration data and adjust 1997 and 2002 NAICS-based census concentration data for deals announced during 1980-1986, 1987-1991, 1992-1996, and 1997-2001, and 2002-2009 respectively. In the 1997 and 2002 censuses, U.S. Census Bureau data are provided on an NAICS basis. One SIC code may correspond to several NAICS codes and the matching relation changes over time. We therefore follow Ali, Klasa, and Yeung (2009) and adjust the data to form an SIC-based Census Herfindahl Index for 1997 and 2002. In particular, we take the sum of the sales-weighted HHI for each NAICS industry under one SIC. All census data are available at http://www.census.gov/econ/concentration.html.
} 
Appendix 3: Variable definitions

All variables are measured at the end of the fiscal year before the merger announcement, unless noted otherwise.

\begin{tabular}{|c|c|}
\hline Variable & Definition \\
\hline Antitrust challenge & $\begin{array}{l}\text { Equals one if the DOJ or FTC challenges a merger according to the FTC } \\
\text { and DOJ's joint "Annual Report to Congress Pursuant to Subsection (j) of } \\
\text { Section 7A of the Clayton Act Hart-Scott-Rodino Antitrust Improvements } \\
\text { Act of 1976", zero otherwise. These reports are available on the FTC } \\
\text { website, } \\
\text { https://www.ftc.gov/policy/reports/policy-reports/ftc-annual-reports }\end{array}$ \\
\hline Bidder past performance & $\begin{array}{l}\text { Bidder's pre-acquisition return on assets, equal to the ratio of operating } \\
\text { income before depreciation to total assets in the year before the merger } \\
\text { announcement. }\end{array}$ \\
\hline Census bidder market share & $\begin{array}{l}\text { Bidder sales in the merging industry divided by census-based total sales of } \\
\text { the merging industry. Census data is available at } \\
\text { http://www.census.gov/econ/concentration.html }\end{array}$ \\
\hline Census Herfindahl Index & $\begin{array}{l}\text { The U.S. Census Bureau estimate of the industry Herfindahl index divided } \\
\text { by } 10000 \text {. Census data is available at } \\
\text { http://www.census.gov/econ/concentration.html }\end{array}$ \\
\hline$\Delta$ Census Herfindal & $\begin{array}{l}\text { Equals } 2 \times \text { percentage of bidder sales in the merging industry } \times \text { percentage } \\
\text { of target sales in the merging industry. The merging industry's total sales is } \\
\text { estimated by the U.S. Census Bureau. Census data is available at } \\
\text { http://www.census.gov/econ/concentration.html }\end{array}$ \\
\hline Census hurdle dummy & $\begin{array}{l}\text { Equals one if a) the Census Herfindahl Index exceeds } 0.18 \text {, and } \Delta \text { Census } \\
\text { Herfindahl Index is no less than } 0.005 \text {, or b) the Census Herfindahl Index is } \\
\text { between } 0.1 \text { and } 0.18 \text {, and } \Delta \text { Census Herfindahl Index is no less than } 0.01 \text {, } \\
\text { zero otherwise. }\end{array}$ \\
\hline Combined CAR & $\begin{array}{l}\text { A market-capitalization-weighted average of the bidder's and target's } \\
\text { market-model-adjusted returns from two days before to two days after, i.e., } \\
(-2,2) \text {, the announcement date. }\end{array}$ \\
\hline Customer CAR (gen & $\begin{array}{l}\text { Market-model-adjusted returns over a }(-2,2) \text { window around the } \\
\text { announcement date to an equal weighted portfolio of all corporate } \\
\text { customers. A generic customer is a Compustat single-segment firm whose } \\
\text { industry procures more than } 1 \% \text { of its input from the merger industry. The } \\
\text { input-output relation is based on the } 1982,1987,1992,1997 \text {, and } 2002 \text { BEA } \\
\text { Use tables, available at } \\
\text { http://www.bea.gov/industry/io_benchmark.htm }\end{array}$ \\
\hline Customer CAR (l & $\begin{array}{l}\text { Market-model-adjusted returns over a }(-2,2) \text { day window around the } \\
\text { announcement date to an equal weighted portfolio of local corporate } \\
\text { customers. A customer firm is local if it locates in the same region as the } \\
\text { bidder or target. }\end{array}$ \\
\hline Customer CAR (re & $\begin{array}{l}\text { Market-model-adjusted returns over a }(-2,2) \text { day window around the } \\
\text { announcement date to an equal weighted portfolio of reliant corporate } \\
\text { customers. A customer firm is reliant if it operates in a customer industry } \\
\text { with the highest customer input coefficient }(C I C) \text { among all customer } \\
\text { industries. CIC is the output value purchased from the merging industry } \\
\text { divided by the customer industry's total output value. }\end{array}$ \\
\hline Customer dependence (generic) & $\begin{array}{l}\text { The generic customer's reliance on the merging industry based on material } \\
\text { purchases equals the weighted CICs of all customer industries, with weights } \\
\text { being the ratio of each customer industry's sales to the aggregate sales of all } \\
\text { customer industries. }\end{array}$ \\
\hline Customer dependence (local) & $\begin{array}{l}\text { The local customer's reliance on the merging industry based on material } \\
\text { purchases equals the weighted CICs of all local customer industries, with } \\
\text { weights being the ratio of each local customer industry's sales to the } \\
\text { aggregate sales of all local customer industries. }\end{array}$ \\
\hline
\end{tabular}




\section{Appendix 3 (continued)}

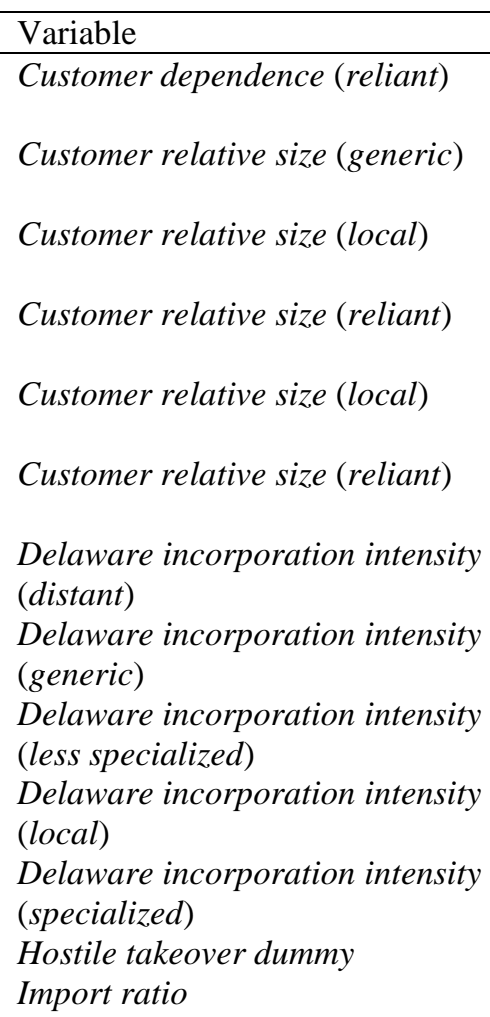

Industry-adjusted stock payment percentage

Industry growth

Ln Bidder market cap.

Relative deal size Rival CAR (distant)

Rival CAR (generic)

Rival CAR (less specialized)

Rival CAR (local)

\section{Definition}

The reliant customer's reliance on the merging industry based on material purchases is the $C I C$ of the reliant customer industry.

The ratio of the average generic customers' market capitalization to the bidder's market capitalization, divided by 100 .

The ratio of the average local customer's market capitalization to the bidder market capitalization, divided by 100 .

The ratio of the average reliant customer's market capitalization to the bidder's market capitalization, divided by 100 .

The ratio of the average local customer's market capitalization to the bidder market capitalization, divided by 100 .

The ratio of the average reliant customer's market capitalization to the bidder's market capitalization, divided by 100 .

The proportion of Delaware incorporated rival firms in the merging industry of the distant rival portfolio, as a decimal.

The proportion of Delaware incorporated rival firms in the merging industry of the generic rival portfolio, as a decimal.

The proportion of Delaware incorporated rival firms in the merging industry of the less specialized rival portfolio, as a decimal.

The proportion of Delaware incorporated rival firms in the merging industry of the distant rival portfolio, as a decimal.

The proportion of Delaware incorporated rival firms in the merging industry of the specialized rival portfolio, as a decimal.

Equals one if a merger is hostile, zero otherwise.

The merging industry's total imports divided by its total domestic supply. Total domestic supply is commodity output minus imports, exports, change in private inventories and sales of scrap/used goods (Streitwieser, 2010). Raw data for import ratio construction is from the 1982, 1987, 1992, 1997 and 2002 BEA Use tables, available at

http://www.bea.gov/industry/io_benchmark.htm

Equals the deal's consideration paid in stock reported by the SDC (calculated as value paid in stock divided by total value) minus the average consideration paid in stock of all horizontal mergers in a merging industry in the year of merger announcement.

The ratio of the median firm's sales in an industry the year before the merger to industry median firm sales three years before.

The logarithm of the bidder market capitalization in \$millions.

The ratio of deal value to the bidder's market capitalization.

Market-model-adjusted return over a $(-2,2)$ window around the announcement date to an equal weighted portfolio of distant rivals. A rival firm is distant if it does not locate in the same region as the bidder or target. Market-model-adjusted return over a $(-2,2)$ window around the announcement date to an equal weighted portfolio of generic rivals. A generic rival is any Compustat firm operating in the merging industry the year before the deal announcement.

Market-model-adjusted return over a $(-2,2)$ window around the announcement date to an equal weighted portfolio of less specialized rivals. A rival firm is less specialized if its $R \& D$ and advertising expenditure the fiscal year before the deal announcement is below the $75^{\text {th }}$ percentile for the industry.

Market-model-adjusted return over a $(-2,2)$ window around the announcement date to an equal weighted portfolio of local rivals. A rival firm is local if it locates in the same region as the bidder or target. 


\section{Appendix 3 (continued)}

\begin{tabular}{ll}
\hline Variable & \multicolumn{1}{c}{ Definition } \\
\hline Rival CAR (specialized) & $\begin{array}{l}\text { Market-model-adjusted return over a }(-2,2) \text { window around the } \\
\text { announcement date to an equal weighted portfolio of specialized rivals. A } \\
\text { rival firm is specialized if its } \mathrm{R} \& \mathrm{D} \text { and advertising expenditure the fiscal } \\
\text { year before the deal announcement is above the } 75^{\text {th }} \text { percentile for the } \\
\text { industry. } \\
\text { The ratio of the average generic rival's market capitalization to the bidder's } \\
\text { market capitalization. } \\
\text { The ratio of the average distant rival's market capitalization to the bidder's } \\
\text { market capitalization. }\end{array}$ \\
Rival relative size (distant) & $\begin{array}{l}\text { The ratio of the average less specialized rival's market capitalization to the } \\
\text { bidder's market capitalization. } \\
\text { The ratio of the average local rival's market capitalization to the bidder's } \\
\text { market capitalization. }\end{array}$ \\
Rival relative size (local) & $\begin{array}{l}\text { The ratio of the average specialized rival's market capitalization to the } \\
\text { bidder's market capitalization. }\end{array}$ \\
Equal relative size (specialized) & $\begin{array}{l}\text { Equals if there is no horizontal merger announcement in the merging } \\
\text { industry in the three years before the merger announcement, zero otherwise. } \\
\text { Equals one if the transaction is conducted via a tender offer, zero otherwise. }\end{array}$ \\
Tender offer dummy &
\end{tabular}




\section{Appendix 4: Instrument justification for wealth effect variables}

\section{Instrument justification for Combined CAR}

For Combined CAR, we selected five instrumental variables, namely Surprise deal dummy, Tender offer dummy, Hostile takeover dummy, Industry-adjusted stock payment percentage, and Bidder past performance. Surprise deal dummy equals one if there are no horizontal mergers in the merging industry in the previous three years. When a deal announcement surprises the market, the wealth effects are more pronounced. It is unlikely, however, that the market can better predict anticompetitive mergers than efficient mergers or vice versa. We follow the spirit of Aktas, de Bodt, and Roll $(2004,2007)$ and use Tender offer dummy, Industry-adjusted stock payment percentage, and Bidder past performance as instruments. Tender offer dummy equals one if a deal is a tender offer and zero otherwise. A tender offer often results in better acquirer wealth effects and long-run post-merger performance (Agrawal and Jaffe, 2000) but as a mode of merger, a tender offer does not determine what drives a merger and should have no link to antitrust intervention. Percentage of stock payment relates to bidder market valuation (Travlos, 1987; Shleifer and Vishny, 2003; Rhodes-Kropf, Robinson, and Viswanathan, 2005), growth, business complementarity, and information asymmetry (Hansen, 1987; Eckbo, Makaew, and Thorburn, 2014) and therefore influences wealth effects. To ensure percentage of stock payment reflects information at the firm level, we adjust it by the average percentage of stock payment of mergers in the same industry. This industry-adjusted percentage of stock payment, as an arrangement of the medium of exchange, does not directly relate to anticompetitive motives and thus is not directly related to antitrust intervention. Hostile takeover dummy equals one if a merger is hostile and zero otherwise. Schwert (2000) finds deal hostility is associated with bidder wealth effects. However, ex ante, deal hostility has no clear bearing on merger motives. Shivdasani (1993) and Schwert (2000) suggest that hostile mergers improve efficiency by removing non-performing boards.

\section{Instrument justification for rival CARs}

For the CARs of rival portfolios, we use three instrumental variables, namely, Surprise deal dummy, Rival relative size (following Aktas, de Bodt, and Roll, 2007), and Delaware incorporation intensity. Rival relative size equals the ratio of a rival's market capitalization to the bidder's market capitalization (Appendix 3 gives a detailed description). It relates to announcement effects because rivals that are similar in size are either more likely to face a competitive disadvantage from a close competitor's merger or are in a better position to capture potential efficiency gains signaled by a horizontal merger. However, although these rivals may be more able to influence antitrust intervention, their incentive to influence is conditional on their wealth effects. Therefore, Rival relative size affects antitrust case selection only through rival wealth effects. Delaware incorporation intensity is the proportion of industry rivals incorporated in Delaware. Delaware Antitakeover Law offers companies protection from unwanted merger proposals, increases merger costs, and makes mergers more difficult to complete (Gaughan, 2015, p.106). This attenuates rival wealth effects related to the merger. However, antitakeover legislation affects efficient and anticompetitive mergers in a similar fashion and does not directly relate to antitrust intervention. 


\section{Instrument justification for customer CARs}

For the CARs of customer portfolios, we instrument using Surprise deal dummy, Customer relative size, and Customer dependence. Customer relative size is relative to bidder market capitalization. Larger customers may be more likely to benefit from the efficiency gains of upstream mergers or sustain the impact of anticompetitive upstream mergers. Customer dependence measures the customer's reliance on the merging industry in terms of material purchases. Reliant customers may have weaker bargaining power and be less likely to receive efficiency gains from an upstream merger. They may be more vulnerable to an anticompetitive upstream merger due to greater material purchase reliance along the supply chain. However, neither instrument relates to a particular type of upstream merger motive. 


\section{Appendix 5: First-step OLS instrumental variable formation}

This table reports the results of first-step OLS regressions of wealth effects on instrumental variables. Customer relative size $e^{+}$in models $1-3$ refers to the ratio of the average market capitalization of the corresponding customer portfolio to the bidder's equity market value. Customer dependence in models 1-3 refers to the weighted CIC of all customer industries of the corresponding customer portfolio, with weights being the ratio of each customer industry's sales to the aggregate sales of all corresponding customer industries. Rival relative size ${ }^{+}$in models $4-8$ refers to the ratio of the average market capitalization of the corresponding rival portfolio to the bidder's equity market value. Delaware incorporation intensity ${ }^{+}$in models $4-8$ refers to the proportion of Delaware incorporated rival firms in the merging industry for the relevant rival portfolio. Appendix 3 defines all variables. $F$-test $\chi^{2}$ reports the joint significance test for the selected exogenous instrumental variables of wealth effects. All variables are winsorized at the $1^{\text {st }}$ and $99^{\text {th }}$ percentiles. $t$-statistics are in parentheses. ${ }^{* * *}$, and ${ }^{* * *}$ denote significance at $10 \%, 5 \%$, and $1 \%$.

\begin{tabular}{|c|c|c|c|c|c|c|c|c|c|}
\hline \multirow[b]{3}{*}{ Independent variable } & \multicolumn{9}{|c|}{ Dependent variable: Announcement effects } \\
\hline & $\begin{array}{c}\text { Customer } \\
\text { CAR } \\
\text { (generic) }\end{array}$ & $\begin{array}{c}\text { Customer } \\
\text { CAR } \\
\text { (local) }\end{array}$ & $\begin{array}{c}\text { Customer } \\
\text { CAR } \\
\text { (reliant) }\end{array}$ & $\begin{array}{c}\text { Rival } \\
\text { CAR } \\
\text { (generic) }\end{array}$ & $\begin{array}{l}\text { Rival } \\
\text { CAR } \\
\text { (local) }\end{array}$ & $\begin{array}{l}\text { Rival } \\
\text { CAR } \\
\text { (distant) }\end{array}$ & $\begin{array}{c}\text { Rival } \\
\text { CAR } \\
\text { (less specialized) }\end{array}$ & $\begin{array}{c}\text { Rival } \\
\text { CAR } \\
\text { (specialized) }\end{array}$ & $\begin{array}{c}\text { Combined } \\
C A R\end{array}$ \\
\hline & 1 & 2 & 3 & 4 & 5 & 6 & 7 & 8 & 9 \\
\hline Import ratio & $\begin{array}{c}0.007 \\
(0.53)\end{array}$ & $\begin{array}{c}0.000 \\
(0.04)\end{array}$ & $\begin{array}{c}0.025 \\
(0.68)\end{array}$ & $\begin{array}{c}-0.004 \\
(-0.29)\end{array}$ & $\begin{array}{r}-0.013 \\
(-0.75)\end{array}$ & $\begin{array}{c}-0.007 \\
(-0.46)\end{array}$ & $\begin{array}{c}0.001 \\
(0.06)\end{array}$ & $\begin{array}{c}-0.025 \\
(-1.21)\end{array}$ & $\begin{array}{l}-0.104^{* *} \\
(-2.13)\end{array}$ \\
\hline Census hurdle dummy & $\begin{array}{c}-0.004 \\
(-0.61)\end{array}$ & $\begin{array}{c}-0.006 \\
(-0.81)\end{array}$ & $\begin{array}{c}0.016 \\
(1.08)\end{array}$ & $\begin{array}{r}0.002 \\
(0.27)\end{array}$ & $\begin{array}{l}-0.004 \\
(-0.61)\end{array}$ & $\begin{array}{r}0.004 \\
(0.67)\end{array}$ & $\begin{array}{r}0.000 \\
(0.07)\end{array}$ & $\begin{array}{r}0.001 \\
(0.07)\end{array}$ & $\begin{array}{c}0.008 \\
(0.49)\end{array}$ \\
\hline Industry growth & $\begin{array}{r}0.000 \\
(0.21)\end{array}$ & $\begin{array}{l}-0.000 \\
(-0.17)\end{array}$ & $\begin{array}{c}-0.005 \\
(-0.73)\end{array}$ & $\begin{array}{c}0.001 \\
(0.39)\end{array}$ & $\begin{array}{c}0.000 \\
(0.21)\end{array}$ & $\begin{array}{r}0.002 \\
(0.64)\end{array}$ & $\begin{array}{r}0.001 \\
(0.71)\end{array}$ & $\begin{array}{c}-0.001 \\
(-0.66)\end{array}$ & $\begin{array}{c}0.001 \\
(0.25)\end{array}$ \\
\hline Relative deal size & $\begin{array}{c}-0.001 \\
(-0.32)\end{array}$ & $\begin{array}{l}-0.002 \\
(-1.05)\end{array}$ & $\begin{array}{c}0.002 \\
(0.25)\end{array}$ & $\begin{array}{c}0.001 \\
(0.52)\end{array}$ & $\begin{array}{c}0.001 \\
(0.50)\end{array}$ & $\begin{array}{c}0.002 \\
(0.96)\end{array}$ & $\begin{array}{c}0.001 \\
(0.66)\end{array}$ & $\begin{array}{c}0.002 \\
(0.57)\end{array}$ & $\begin{array}{c}0.014 \\
(1.38)\end{array}$ \\
\hline Census bidder market share & $\begin{array}{r}0.002 \\
(0.69)\end{array}$ & $\begin{array}{c}-0.000 \\
(-0.09)\end{array}$ & $\begin{array}{l}-0.002 \\
(-0.29)\end{array}$ & $\begin{array}{l}-0.000 \\
(-0.04)\end{array}$ & $\begin{array}{c}-0.001 \\
(-0.19)\end{array}$ & $\begin{array}{r}0.002 \\
(0.58)\end{array}$ & $\begin{array}{l}-0.001 \\
(-0.48)\end{array}$ & $\begin{array}{r}0.001 \\
(0.34)\end{array}$ & $\begin{array}{c}0.004 \\
(0.50)\end{array}$ \\
\hline Ln Bidder market cap. & $\begin{array}{c}0.000 \\
(0.15)\end{array}$ & $\begin{array}{c}0.001 \\
(0.68)\end{array}$ & $\begin{array}{l}-0.001 \\
(-0.57)\end{array}$ & $\begin{array}{c}0.000 \\
(0.01)\end{array}$ & $\begin{array}{l}-0.000 \\
(-0.27)\end{array}$ & $\begin{array}{c}-0.000 \\
(-0.20)\end{array}$ & $\begin{array}{c}0.001 \\
(0.76)\end{array}$ & $\begin{array}{c}-0.001 \\
(-1.09)\end{array}$ & $\begin{array}{l}-0.008^{* * * *} \\
(-2.89)\end{array}$ \\
\hline Surprise deal dummy & $\begin{array}{l}0.006^{* *} \\
(2.19)\end{array}$ & $\begin{array}{l}0.012^{* * * *} \\
(3.13)\end{array}$ & $\begin{array}{l}0.025^{* * * *} \\
(3.45)\end{array}$ & $\begin{array}{r}0.004 \\
(1.57)\end{array}$ & $\begin{array}{c}0.007 \\
(1.84)\end{array}$ & $\begin{array}{c}0.003 \\
(0.95)\end{array}$ & $\begin{array}{l}0.006^{*} \\
(1.85)\end{array}$ & $\begin{array}{c}0.001 \\
(0.24)\end{array}$ & $\begin{array}{c}0.018^{*} \\
(1.77)\end{array}$ \\
\hline Customer relative size $e^{+}$ & $\begin{array}{c}-0.007 \\
(-0.46)\end{array}$ & $\begin{array}{l}0.021 \\
(0.81)\end{array}$ & $\begin{array}{c}0.002 \\
(0.07)\end{array}$ & & & & & & \\
\hline Customer dependence $e^{+}$ & $\begin{array}{l}-0.023 \\
(-0.91)\end{array}$ & $\begin{array}{r}0.029 \\
(0.69)\end{array}$ & $\begin{array}{c}0.028 \\
(0.59)\end{array}$ & & & & & & \\
\hline Rival relative size ${ }^{+}$ & & & & $\begin{array}{l}-0.005 \\
(-0.62)\end{array}$ & $\begin{array}{l}-0.021 \\
(-1.27)\end{array}$ & $\begin{array}{c}-0.003 \\
(-0.48)\end{array}$ & $\begin{array}{l}-0.002 \\
(-0.31)\end{array}$ & $\begin{array}{l}-0.018^{* * *} \\
(-2.07)\end{array}$ & \\
\hline $\begin{array}{l}\text { Delaware incorporation } \\
\text { intensity }^{+}\end{array}$ & $v$ & & & $\begin{array}{l}-0.001 \\
(-0.15)\end{array}$ & $\begin{array}{r}0.005 \\
(0.50)\end{array}$ & $\begin{array}{l}-0.001 \\
(-0.16)\end{array}$ & $\begin{array}{r}0.000 \\
(0.00)\end{array}$ & $\begin{array}{l}-0.004 \\
(-0.45)\end{array}$ & \\
\hline Tender offer dummy & & & & & & & & & $\begin{array}{l}0.017^{* *} \\
(2.00)\end{array}$ \\
\hline Hostile takeover dummy & & & & & & & & & $\begin{array}{c}0.024 \\
(1.56)\end{array}$ \\
\hline
\end{tabular}


Appendix 5 (continued)

\begin{tabular}{|c|c|c|c|c|c|c|c|c|c|}
\hline \multirow[b]{3}{*}{ Independent variable } & \multicolumn{9}{|c|}{ Dependent variable: Announcement effects } \\
\hline & $\begin{array}{l}\text { Customer } \\
\text { CAR } \\
\text { (generic) }\end{array}$ & $\begin{array}{c}\text { Customer } \\
\text { CAR } \\
\text { (local) }\end{array}$ & $\begin{array}{l}\text { Customer } \\
\text { CAR } \\
\text { (reliant) }\end{array}$ & $\begin{array}{c}\text { Rival } \\
\text { CAR } \\
\text { (generic) }\end{array}$ & $\begin{array}{c}\text { Rival } \\
\text { CAR } \\
\text { (local) } \\
5\end{array}$ & $\begin{array}{c}\text { Rival } \\
\text { CAR } \\
\text { (distant) }\end{array}$ & $\begin{array}{c}\text { Rival } \\
\text { CAR } \\
\text { (less specialized) }\end{array}$ & $\begin{array}{c}\text { Rival } \\
\text { CAR } \\
\text { (specialized) }\end{array}$ & $\begin{array}{l}\text { Combined } \\
\text { CAR }\end{array}$ \\
\hline & 1 & 2 & 3 & 4 & 5 & 6 & 7 & 8 & 9 \\
\hline $\begin{array}{l}\text { Industry-adjusted stock } \\
\text { payment percentage } \\
\text { Bidder past performance }\end{array}$ & & & & & & & & & $\begin{array}{c}0.190 \\
(0.91) \\
0.063 \\
(1.28)\end{array}$ \\
\hline Year effects & Y & $\mathrm{Y}$ & $\mathrm{Y}$ & Y & $\mathrm{Y}$ & & Y & $\mathrm{Y}$ & $\mathrm{Y}$ \\
\hline$R^{2}$ & 0.09 & 0.10 & 0.14 & 0.09 & 0.11 & 0.10 & 0.09 & 0.12 & 0.21 \\
\hline$F$-test $\chi^{2}$ & 5.89 & $12.94^{* * *}$ & $13.55^{* * *}$ & 2.68 & 4.22 & 1.10 & 3.58 & 4.92 & $15.63^{* * *}$ \\
\hline Observations & 372 & 354 & 266 & 372 & 363 & 371 & 371 & 372 & 372 \\
\hline
\end{tabular}

